UNIVERSIDADE DE SÃO PAULO Faculdade de Filosofia, Ciências e Letras de Ribeirão Preto Departamento de Educação, Informação e Comunicação Programa de Pós-Graduação em Educação

A concepção de gestão escolar na grande mídia no Brasil: um estudo sobre a revista Veja, no período de 1997 a 2014

Eduardo Villela Machado

Ribeirão Preto 
Eduardo Villela Machado

A concepção de gestão escolar na grande mídia no Brasil: um estudo sobre a revista Veja, no período de 1997 a 2014

Dissertação de Mestrado apresentada ao Programa de Pós-graduação em Educação da Faculdade de Filosofia, Ciências e Letras de Ribeirão Preto da Universidade de São Paulo.

Área de Concentração: Educação.

Orientadora: Prof ${ }^{\mathrm{a}}$. Dr ${ }^{\mathrm{a}}$. Teise de Oliveira Guaranha Garcia.

Versão corrigida. A versão original eletrônica encontra-se disponível na Biblioteca Central USP - Ribeirão Preto e na Biblioteca Digital de Teses e Dissertações da USP (BDTD).

Ribeirão Preto 
Autorizo a reprodução e divulgação total ou parcial deste trabalho, por qualquer meio convencional ou eletrônico, para fins de estudo e pesquisa, desde que citada a fonte.

MACHADO, Eduardo Villela

A concepção de gestão escolar na grande mídia no Brasil:

um estudo sobre a revista Veja, no período de 1997 a 2014

85 p. : il. ; $30 \mathrm{~cm}$

Dissertação de Mestrado, apresentada à Faculdade de Filosofia Ciências e Letras de Ribeirão Preto/USP. Área de concentração: Educação.

Orientador: Teise de Oliveira Guaranha Garcia.

1. Política Educacional. 2. Gestão Democrática. 3. Participação. 
Eduardo Villela Machado

\section{A concepção de gestão escolar na grande mídia no Brasil: um estudo sobre a revista Veja, no período de 1997 a 2014}

Dissertação de Mestrado apresentada ao Programa de Pós-Graduação em Educação da Faculdade de Filosofia, Ciências e Letras de Ribeirão Preto da Universidade de São Paulo, como requisito parcial para obtenção do título de Mestre em Educação.

Aprovado em:

\section{Banca Examinadora}

Prof. Dr. Instituição:

Julgamento: Assinatura:

Prof. Dr. Instituição: Julgamento: Assinatura:

Prof. Dr. Instituição: Julgamento: Assinatura:

Prof. Dr. Instituição:

Julgamento: Assinatura:

Ribeirão Preto 
Dedico este trabalho à minha família, que estiveram sempre ao meu lado e que, com muito esforço, propiciaram a oportunidade para que eu pudesse estudar, sonhar e tornar meus sonhos reais. 


\section{AGRADECIMENTOS}

Agradeço a todos que contribuíram de alguma maneira, direta ou indiretamente, para a construção e realização desse trabalho.

A Professora Teise pela orientação, pela compreensão nos momentos difíceis e pela sabedoria de fazer as criticas com a devida serenidade e firmeza necessária.

A banca de qualificação e defesa, composta por Prof ${ }^{a}$ Dra. Silvana e Prof. Dr. Sérgio, que trouxeram contribuições valiosas para o trabalho.

Ao GREPPE, principalmente aos membros de Ribeirão Preto, que estiveram sempre presentes e construindo um coletivo necessário a pesquisa, para que muitas vezes a caminhada não fosse solitária.

A minha companheira Rita que sempre teve muito amor e paciência para me ajudar a atravessar esse caminho árduo de pesquisa. 


\section{RESUMO}

Este trabalho apresenta dados de pesquisa acerca da temática gestão escolar presentes em um veículo de comunicação de massa. Trata-se da revista Veja. A pesquisa coletou e analisou dados referentes ao tema gestão escolar/educacional presente nos conteúdos da revista Veja ao longo de 18 anos de publicações (1997-2014). O critério utilizado para escolha da revista Veja como objeto de análise foi por se tratar de um veículo de massa que tem abrangência nacional e ser o mais lido no segmento de revistas semanais. O objetivo central deste trabalho foi o de caracterizar, compreender e analisar o conteúdo sobre gestão escolar presente na revista. Os procedimentos para alcançar os objetivos visaram selecionar os conteúdos que abordavam o tema educação e depois separar aqueles que especificamente tratavam da gestão escolar. Além disso, este trabalho faz inferências sobre a concepção de gestão escolar encontrada na revista Veja ao longo desses 18 anos (19972014). Para levantamento dos dados recorreu-se as orientações teórico-metodológicas da análise de conteúdo na perspectiva de Laurence Bardin. Para análise, foram verificadas todas as edições da revista Veja do ano de 1997 até de 2014. Como o objeto deste trabalho são as veiculações acerca do tema gestão escolar/educacional, a primeira movimentação foi levantar quais publicações eram sobre educação. Posteriormente, foi aprofundada a análise, caracterizando quais dessas publicações sobre educação abordavam a temática gestão escolar/educacional. Acerca das inferências sobre a concepção de gestão presente na revista, é importante destacar a defesa que a Revista Veja faz do setor privado e de conceitos presentes na administração tipicamente capitalista como modelo genérico que pode ser transplantado para a educação pública como ideal de qualidade na educação. Modelo esse que vai de encontro com a natureza e especificidade do caráter pedagógico desenvolvido no processo de trabalho no interior da escola. Para aporte teórico da análise sobre a natureza especifica do processo pedagógico foi-se utilizado especialmente o autor Vitor Paro.

Palavras-chave: Gestão-escolar. Mídia não especializada. Concepção de gestão. 


\section{ABSTRACT}

This paper presents research data on the subject of school management present in a mass communication vehicle. This is Veja magazine. The research collected and analyzed data referring to the subject school / educational management present in the contents of Veja magazine over 18 years of publications (1997-2014). The criterion used to choose Veja magazine as the object of analysis was because it is a mass vehicle that has national coverage and is the most read in the segment of weekly magazines. The main objective of this work was to characterize, understand and analyze the content on school management present in the journal. The procedures for achieving the objectives were to select the content that addressed the theme of education and then separate those that specifically deal with school management. In addition, this paper draws inferences about the conception of school management found in Veja magazine over the course of these 18 years (1997-2014). For data collection we used the theoretical-methodological guidelines of content analysis from Laurence Bardin's perspective. For the analysis, all editions of Veja magazine from 1997 to 2014 were verified. As the object of this work is the publications about the topic school / educational management, the first move was to find out which publications were about education. Subsequently, the analysis was deepened, characterizing which of these publications on education addressed the issue of school / educational management. Regarding the inferences about the management conception present in the magazine, it is important to highlight Veja's defense of the private sector and concepts present in typically capitalist administration as a generic model that can be transplanted into public education as an ideal of quality in education. This model of the private sector confronts the nature and specificity of the pedagogical character developed in the work process inside the school. For the theoretical contribution of the analysis on the specific nature of the pedagogic process, the author Vitor Paro was especially used.

Keywords: School management. Non-specialized media. Management conception 


\section{LISTA DE TABELAS}

TABELA 1 - Inserções do tema Administração Gerencialista por tipo de

publicação

TABELA 2 - Inserções do tema Avaliações Externas por tipo De

publicação 46

TABELA 3 - Inserções do tema Parcerias por tipo de publicação …………………......

TABELA 4 -Inserções do tema Diretor Escolar por tipo De

publicação $\quad 54$ 


\section{LISTA DE SILGAS E ABREVIAÇÕES}

ANER - Associação Nacional de Editores de Revistas

BID - Banco Interamericano de Desenvolvimento

Bovespa - Bolsa de Valores de São Paulo

CAPES - Coordenação de Aperfeiçoamento de Pessoal de Nível Superior

FFCLRP - Faculdade de Filosofia Ciências e Letras de Ribeirão Preto

FUNDEF - Fundo de Manutenção e Desenvolvimento do Ensino Fundamental e

Valorização do Magistério

FVC - Fundação Victor Civita

GREPPE - Grupo de Estudos e Pesquisas em Políticas Educacionais

IAS - Instituto Ayrton Senna

IDEB - Índice de Desenvolvimento da Educação Básica

INPES - Instituto de Pesquisa em Saúde

INSPER - Instituição de Ensino e Pesquisa, sem fins lucrativos, nas áreas de administração, economia, direito e engenharia

IPEA - Instituto de Pesquisa Econômica Aplicada

LDB - Lei de Diretrizes e Base da Educação

MEC - Ministério da Educação

OCDE - Organização para Cooperação e Desenvolvimento Econômico

ONG - Organização Não Governamental

PIB - Produto Interno Bruto

PISA - Programa Internacional de Avaliação de Aluno

PNLD - Programa Nacional do Livro Didático

PUC - Pontifícia Universidade Católica

RBS - Rede Brasil Sul de Televisão (afiliada da rede Globo)

SGI - Sistema de Gerenciamento Integrado do Grupo Pitágoras

UFMG - Universidade Federal de Minas Gerais

UNESP - Universidade Estadual Paulista

UNICAMP - Universidade Estadual de Campinas

USP - Universidade de São Paulo 


\section{SUMÁRIO}

1- INTRODUÇÃO

1.1 - Metodologia da Pesquisa.

1.2 - Procedimentos Metodológicos

2 - CARACTERIZAÇÕES DO GRUPO ABRIL E REVISTA VEJA

2.1 - O grupo Abril e a incursão no campo educacional

2.2 - Revista Veja

2.3 - Os articuladores do tema Educação e gestão escolar na revista Veja

3 - REVISTA VEJA E A EDUCAÇÃO: DEZOITO ANOS DE PUBLICAÇÕES E DOIS MOMENTOS BEM DISTINTOS

3.1 - Categorias de análise referentes ao tema gestão escolar 38

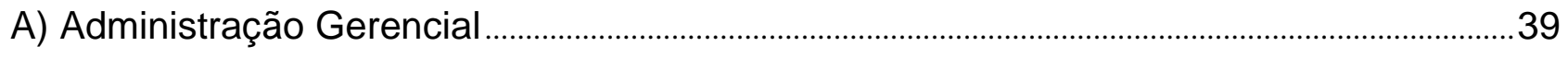

B) Avaliações externas ........................................................................................................... 45

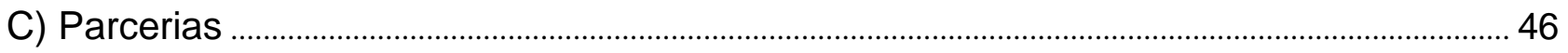

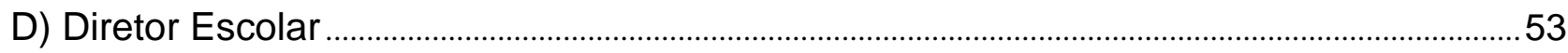

4 - O CONTEÚDO SOBRE GESTÃO ESCOLAR DENTRO DA REVISTA VEJA - UMA ANÁLISE SOBRE A CONCEPÇÃO DE GESTÃO PRESENTE

4.1 - Administração gerencial e a lógica empresarial para dentro da escola

4.2 - A natureza e especificidade do processo pedagógico

5 - CONSIDERAÇÕES FINAIS 


\section{1 - INTRODUÇÃO}

Esta pesquisa pretende fazer uma incursão sobre o tema gestão escolar presente nos conteúdos de uma mídia impressa não especializada. A motivação deste estudo se dá por conta do interesse cada vez maior dos veículos de comunicação impressos em escrever sobre educação (PRESOTTI, p. 38, 2012). O foco deste estudo trata mais especificamente sobre o tema gestão escolar, sobretudo na escola pública. Tal motivação começa a se materializar no ano de 2013 quando eu e minha orientadora conversávamos sobre a possibilidade de realizar uma pesquisa que enfocasse um veículo de comunicação e, assim, desvelasse por meio da pesquisa, qual concepção de gestão escolar seria encontrada no corpo das publicações. Foi em 2013, ainda em meu último ano de graduação em Pedagogia pela Faculdade de Filosofia, Ciências e Letras da USP de Ribeirão Preto (FFCLRP - USP), que comecei a traçar meu percurso que culminaria no projeto apresentado no ano subsequente ao programa de pós-graduação da mesma faculdade, com o intuito de investigar as concepções de gestão de um determinado veículo de mídia não impresso. É importante ressaltar que desde 2013 participo das discussões do Grupo de Estudos e Pesquisas em Políticas Educacionais (GREPPE) que promovem discussões sobre políticas

públicas educacionais que sedimentara uma base sólida para a emersão do interesse em desenvolver minha pesquisa. Neste sentido, é necessário pontuar que meu estudo dialoga com uma pesquisa maior cujo objetivo é o mapeamento das estratégias de privatização da Educação Básica no Brasil (2005-2015). Pesquisa esta desenvolvida pelo GREPPE. O GREPPE é um grupo interinstitucional, que congrega pesquisadores, pós-graduandos e graduandos das três universidades estaduais paulistas, Universidade de São Paulo - USP, Universidade Estadual de Campinas - UNICAMP e Universidade Estadual Paulista UNESP. Organizado a partir do contexto da produção coletiva de uma pesquisa acerca do Fundo de Manutenção e Desenvolvimento do Ensino Fundamental e Valorização do Magistério (FUNDEF), o GREPPE desde então desenvolve pesquisas interinstitucionais e coletivas, por conceber a coletividade como meio de qualificar o debate sobre políticas públicas educacionais (ADRIÃO, 2012). A professora doutora Teise Guaranha de Oliveira Garcia (orientadora deste trabalho) é a coordenadora regional pela USP Ribeirão Preto do GREPPE. 
Ainda antes de apresentar os objetivos da pesquisa, ressalto sobre o importante debate entre eu e minha orientadora sobre qual veículo escolher para análise. Num primeiro momento decidimos que o veículo selecionado seria aquele que tivesse inserções mensalmente ou semanalmente, para que a pesquisa pudesse contemplar uma abordagem temporal maior, pois com um veículo de inserção diária a análise de uma mesma quantidade de publicações restringiria o recorte temporal. Após isso, tecemos duas linhas de possibilidades de investigação; veículo especializado em educação ou não especializado em educação. Sobre aqueles especializados em educação chegamos a três revistas: Nova Escola, Gestão Escolar e Gestão Educacional. As duas últimas foram descartadas por serem revistas com menos de cinco anos de existência e, portanto, não comportarem o recorte temporal pensado. Já quanto à Nova Escola, houve a discussão sobre sua proposta editorial não ser especifica para gestão escolar. Foi nesse sentido que se optou por escolher um veículo não especializado em educação, mas que tratasse do tema com viés de autoridade científica na área. Além disso, deveria ser uma mídia que tivesse abrangência nacional e muitas tiragens. Nesse sentido chegamos à revista Veja. $\mathrm{O}$ critério utilizado para escolha da revista Veja como objeto de análise foi por se tratar de um veículo de massa que tem abrangência nacional e ser o mais lido no segmento de revistas semanais. Segundo dados da Associação Nacional de Editores de Revistas (ANER) a circulação média de edições da revista Veja nos últimos três anos foi:

- 2012 - 1.070 .926 edições semanais

- 2013 - 1.085 .536 edições semanais

- $2014-1.167 .928$ edições semanais

Estes números são três vezes maiores que o segundo colocado com maior número de circulações. Ademais, na pesquisa sobre o veículo mais admirado do Brasil realizado pelo grupo Troiano de Branding desde o ano 2000, Veja liderou todos os anos até 2014 (último levantamento para este estudo). Além de se tratar da maior revista em circulação nacional, Veja publica conteúdos sobre educação com certa frequência. Portanto, esta é a justificativa pelo qual esta revista foi escolhida como objeto de análise desta pesquisa.

O objetivo central deste trabalho é caracterizar, compreender e analisar o conteúdo sobre gestão escolar presente na revista. Os procedimentos para alcançar os objetivos visam selecionar os conteúdos que abordam o tema educação e depois separar aqueles 
que especificamente tratam da gestão escolar. Além disso, este trabalho pretende fazer inferências sobre a concepção de gestão escolar/educacional encontrada na revista Veja ao longo de 18 anos de publicações (1997-2014). O motivo por esta escolha temporal para análise é que 1997 foi o primeiro ano após a promulgação da Lei de Diretrizes e Base da Educação (LDB 1996). Esta lei materializa em seus artigos 14 e 15 as seguintes determinações sobre o principio da gestão democrática na escola pública.

- Art. 14 - Os sistemas de ensino definirão as normas da gestão democrática do ensino público na educação básica, de acordo com as suas peculiaridades e conforme os seguintes princípios:

- I. Participação dos profissionais da educação na elaboração do projeto pedagógico da escola;

- II. Participação das comunidades escolar e local em conselhos escolares ou equivalentes.

- Art. 15 - Os sistemas de ensino assegurarão às unidades escolares públicas de educação básica que os integram progressivos graus de autonomia pedagógica e administrativa e de gestão financeira, observadas as normas de direito financeiro público.

Essa perspectiva é importante para analisar a concepção de gestão escolar no interior da revista.

No primeiro capítulo desta dissertação se encontra os objetivos do trabalho e a metodologia utilizada: análise de conteúdo (BARDIN, 1977). No segundo capítulo faço uma caracterização do grupo Abril, Revista Veja e principais articulistas que escrevem na revista.

No terceiro capítulo apresento os dados coletados e pontuo algumas inferências a respeito dos temas selecionados para análise. Por exemplo, a respeito do papel do diretor que é colocado revista como ator principal pela execução dos objetivos escolares. Para esta discussão apoio meu suporte teórico nas contribuições de Vitor Paro quando trata da dupla missão antagônica em princípios que o diretor escolar exerce dentro da escola (PARO 2012). Já no quarto capítulo é discutida a perspectiva, defendida pela revista Veja, de transposição da lógica gerencial para dentro da escola, por meio de testes padronizados em larga escala, priorizar as faculdades cognitivas, especialmente as ligadas às linguagens de Português e Matemática. Para discussão é utilizado, sobretudo, o referencial de Luiz 
Carlos de Freitas. Ademais, é discutida no capítulo quatro a natureza e especificidade do caráter pedagógico. Perspectiva que se contrapõe a qualquer tentativa de adequação dos modelos administrativas do setor privado para a escola, que tem uma racionalidade interna especifica. Para esta discussão é novamente é utilizada as contribuições de Vitor Paro, além de Silvana de Souza. Por fim, este trabalho tece suas considerações finais, deixando claro que esta pesquisa tentou contribuir, mesmo que de maneira ainda inicial, para compreensão dos conteúdos que são publicados na Revista Veja (como exemplo e expressão da grande mídia impressa no Brasil) sobre educação, especificamente os que tratam sobre gestão escolar e políticas educacionais.

\section{1 - Metodologia de Pesquisa}

Esta pesquisa apresenta-se por um lado com um escopo quantitativo, pois revela dados referentes a publicações de 18 anos da revista Veja, e por outro lado sob a ótica da análise qualitativa dos dados levantados. A pesquisa foi feita mediante consultas ao acervo digital da revista Veja, que disponibiliza todas as suas edições digitalizadas pelo sitio http://veja.abril.com.br/acervodigital/home.aspx. O recurso tecnológico para acesso às edições tenta simular a experiência de manusear a revista fisicamente. Com o recurso é possível folhear as páginas da revista para trás e para frente, escolher a página que deseja acessar pela numeração e avançar rapidamente selecionando o tema de interesse no índice da revista. Foram analisadas todas as edições da revista ao longo desses 18 anos de publicações. Por se tratar de um recorte temporal de muitos anos, optou-se para levantamento dos dados a análise de conteúdo na perspectiva de Laurence Bardin (1977).

Para organização da análise dos dados, BARDIN concebe três polos cronológicos para organizar o conteúdo a ser explorado:

1) pré-análise

2) a exploração do material

3) o tratamento dos resultados, a inferência e a interpretação. 


\section{Figura 3: Fases do Processo de Análise de Conteúdo}

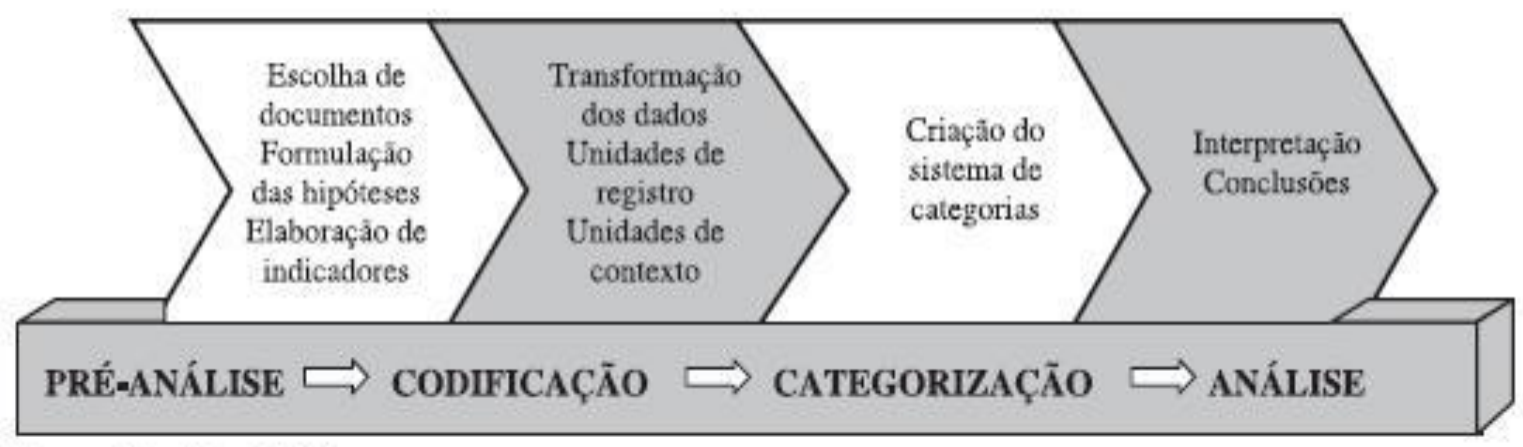

Fonte: Bardin, 1977.

Nas palavras da autora, a pré-análise:

...é a fase de organização propriamente dita. Corresponde a um período de intuições, mas, tem por objetivo tornar operacionais e sistematizar as ideias iniciais, de maneira a conduzir a um esquema preciso do desenvolvimento das operações sucessivas num plano de análise. Recorrendo ou não ao ordenador, trata-se de estabelecer um programa que, podendo ser flexível (quer dizer, que permita a introdução de novos procedimentos no decurso da análise), deve, no entanto, ser preciso.

Geralmente, esta primeira fase possui três missões: a escolha dos documentos a serem submetidos à análise, a formulação das hipóteses e dos objetivos e a elaboração de indicadores que fundamentam a interpretação final. (BARDIN, 1977, p. 95)

\section{2 - Procedimentos Metodológicos}

Para análise, foram verificadas todas as edições da revista Veja do ano de 1997 até de 2014. Como o objeto deste trabalho são as veiculações acerca do tema gestão escolar, a primeira movimentação foi levantar quais publicações eram sobre educação. Posteriormente para aprofundar a análise, foi feito um movimento para identificar quais dessas publicações sobre educação abordavam a temática gestão escolar. 
Para análise das publicações destes autores a seguir é utilizado o critério de analisar o tema na perspectiva de codificação de Bardin. A mesma define esta forma de escolha (tema) para análise como:

...unidade de significação que se liberta naturalmente de um texto analisado segundo certos critérios relativos à teoria que serve de guia à literatura. $\mathrm{O}$ texto pode ser recortado em ideias constituintes, em enunciados e proposições portadores de significações isoláveis... Fazer uma análise temática consiste em descobrir os <núcleos de sentidos> que compõem a comunicação e cuja presença, ou frequência de aparição podem significar alguma coisa para o objetivo analítico escolhido... O tema é geralmente utilizado como unidade de registro para estudar motivações de opiniões, de atitudes, de valores, de crenças, de tendências, etc. (BARDIN, 1977, p.105)

É importante ressaltar que os movimentos de pré-análise e exploração do material são movimentos que se interpenetram e podem não necessariamente acontecem em ordem cronológica segundo BARDIN. 


\section{2 - CARACTERIZAÇÕES DO GRUPO ABRIL E REVISTA VEJA}

Este capítulo pretende discorrer acerca de caracterizações do grupo Abril, passando rapidamente pela sua história até a atuação no mercado financeiro com produtos educacionais e grupo financeiro da educação. Além disso, o capitulo apresenta de forma breve fundações que, ou é mantida pelo grupo Abril, ou tem parcerias com o mesmo, além de projetos assumidos pelo grupo que tratam especificamente do tema educação.

Também é feito um esforço de caracterizar os articulistas que escrevem para a Revista Veja e outros atores que aparecem em entrevistas nas páginas amarelas da revista para tratar de temas como gestão escolar e/ou políticas públicas educacionais.

\section{1 - O grupo Abril e a incursão no campo educacional}

O inicio da trajetória da editora Abril se dá em 1950 e foi marcada pelo lançamento da revista em quadrinhos $O$ Pato Donald. Fundada por Victor Civita, um ítalo-americano que migrou para o Brasil. No início a editora contava apenas com as publicações de personagens em quadrinhos da Disney. Foi na década seguinte que começou a diversificar as suas publicações. Em 1961, foi criada a revista Claudia. Já em 1964, o Guia 4 rodas do Brasil. Em 1966, foi a vez da criação da revista Realidade. Já em 1968 é criada a revista Veja. Fundada pelos jornalistas Roberto Civita e Mino Carta. Com o passar dos anos várias revistas são criadas. Exame e Placar na década de 70. Super Interessante na década de 80. É ainda nesta década, em 1986 que foi fundada a revista Nova Escola. Revista que trata sobre as questões que circundam o campo educacional.

Outro braço de atuação do Grupo Abril na educação é a Fundação Victor Civita (FVC), fundada em 1985. Criada com o objetivo declarado de reverter parte dos lucros do Grupo para a sociedade, a Fundação tem como carro-chefe a educação. As principais iniciativas da instituição são: a revista Nova Escola, a revista Gestão Escolar, o site de Nova Escola, o prêmio Victor Civita (Educador nota 10), a Semana da Educação e a Área de Estudos e Pesquisas Educacionais.

A missão da Fundação Victor Civita descrita em seu endereço eletrônico é: "Construir e disseminar conhecimentos e valorizar práticas da Educação Básica que auxiliem educadores a enfrentar os desafios de seu tempo. " (FUNDAÇÃO VICTOR CIVITA, 2015). 
Desde sua criação a Fundação Victor Civita sempre teve sua atuação ligada à área educacional.

Já em 1986, atua na criação da revista Nova Escola. Em 1988, participa da criação da revista SALA DE AULA. Em 1998, a Fundação organiza a primeira edição do Prêmio Victor Civita Professor Nota 10. Premiação que acontece anualmente até a presente data. A partir de 2014 a premiação passa a ter parceria da Fundação Roberto Marinho e das Organizações Globo e passa a se chamar Prêmio Educador Nota 10. Segundo informações disponíveis no sitio da Fundação Victor Civita o Prêmio Educador Nota 10:

Criado em 1998, o Prêmio Educador Nota 10 reconhece professores da Educação Infantil e do Ensino Fundamental e também gestores escolares de todo o país. Aproximadamente 3.000 educadores, professores, gestores escolares e coordenadores pedagógicos, de diversos segmentos de ensino, inscrevem seu trabalho a cada edição do Prêmio em diferentes áreas de conhecimento. Uma comissão selecionadora, composta por profissionais da Educação, especialistas nas diversas disciplinas, analisa todos os trabalhos recebidos e, entre eles, são escolhidos os 50 finalistas e entre os finalistas são escolhidos os dez Educadores Nota 10. Nessas 18 edições, reconhecemos 191 educadores, entre professores e gestores, e entregamos aproximadamente 2,2 milhões de reais em prêmios. Os trabalhos premiados são ideias simples e corajosas que mostram a importância da aprendizagem de crianças e jovens e a tarefa de mantê-los numa boa escola, trabalho esse indispensável para a transformação deste país numa nação melhor e mais justa. (FUNDAÇÃO VICTOR CIVITA, 2015)

A partir de 2009 a Fundação participa da criação da revista Gestão Escolar. Em 2012, a Fundação Victor Civita disponibiliza plataforma de formação online e inicia pilotos dos Cursos Online Nova Escola de Leitura, em parceria com a Fundação Itaú Social. Em 2013 a Fundação inicia pilotos dos Cursos Online Nova Escola de Matemática, em parceria com a Fundação Bradesco e o Instituto Jaime Câmara.

A partir dos anos 2000, o Grupo Abril passou a adquirir algumas editoras de livros didáticos. As editoras Áticas e Scipione foram compradas ainda em 2004. Em 2007, foi 
criado o Abril Educação. Uma parte da Abril que passou a integrar as editoras adquiridas. Além delas, foram comprados os sistemas de ensino Anglo e Maxi.

Segundo relatório de pesquisa produzido pelo GREPPE (Grupo de Estudo e Pesquisas em Políticas Educacionais) que trata de sistemas de ensino privado na educação pública brasileira, a Abril Educação:

...separou-se, em 2010, do Grupo Abril e se constituiu como editora, mantendo-se, até fevereiro de 2015, sob o controle do Grupo Abril, fundado em 1950 e administrado pela Abrilpar, holding pertencente à família Civita, fundadora do grupo. A Abrilpar, entre outros negócios, controla a Abril Mídia, responsável pela veiculação da maior revista do país, a revista Veja, com 1,08 milhão de exemplares em 2013, segundo o Instituto Verificador de Comunicação (IVC). (ADRIAO, et al, 2015, p. 35)

Em 2011, a Abril Educação começa a ter capital na Bolsa de Valores de São Paulo (Bovespa). Segundo PRESOTTI, 2012:

Após comemorar os recursos levantados com a venda das ações disponibilizadas, o presidente da Abril Educação, Manoel Amorim, demarcou os interesses de investimento da empresa (Valor Econômico online, 5 set. 2011)17: "Nosso foco é a base, ou seja, a formação anterior ao ensino superior. Acreditamos que é preciso ter uma boa formação na base para o aluno cursar uma universidade ou um curso profissionalizante". (PRESOTTI, 2012, p. 44)

Importante destacar esse ponto para compreender os interesses que tal organização tem quando trata do tema educação, sobretudo gestão escolar. Ainda segundo PRESOTTI: 
É interessante perceber como a representação construída no site da empresa Abril Educação se reveste de um compromisso com a qualidade da educação e da formação de professores do País, buscando uma legitimidade que encobre os interesses econômicos de ocupação de um espaço estratégico e de liderança em um mercado lucrativo e em expansão. Cabe destacar que, entre os clientes disputados nesse mercado ascendente, incluem-se os governos municipais, estaduais e federal, que contratam consultorias, sistemas de ensino e compram um impressionante volume de materiais didáticos. Em 2011, a Abril Educação forneceu, através do PNLD / MEC, 57 milhões de livros das editoras Ática e Scipione e do sistema de ensino Ser às escolas públicas e particulares, estimando que $60 \%$ dos alunos do Brasil estudariam em seus livros. Dado que mais de $85 \%$ dos alunos da educação básica estão matriculados nas escolas públicas e recebem o material didático gratuitamente, são as diversas instâncias do Poder Público os maiores clientes da empresa Abril Educação. (PRESOTTI, 2012, p. 45)

O relatório de pesquisa produzido pelo GREPPE apresenta também relevante contribuição para elucidar os interesses corporativos de grupos que incidem sua influência na educação, entre eles, o Abril Educação. A inserção deste grupo na bolsa de valores, segundo o relatório, demonstra uma preocupação sobre as potencialidades de expansão do mercado educacional brasileiro no que tange às quantidades de vagas na educação pública e criação de novas escolas privadas: 
As corporações, por sua vez, integram um cenário complexo de grandes e vultosas negociações. Três grupos - Abril Educação, Pearson e Santillana de capital aberto, protagonizaram recentemente grandes negociações em bolsa de valores, envolvendo a venda dos sistemas privados de ensino para redes públicas. Destaca-se que neste mercado as matrículas públicas são os "ativos" das empresas (ADRIÃO et al., 2009; ADRIÃO, 2009; ADRIÃO et al., 2013). Este aspecto merece especial atenção, uma vez que para além das negociações decorrentes da compra de produtos para atender às diferentes demandas das escolas públicas, processo identificado há mais de duas décadas no Brasil e também em outras partes do mundo (HILL, 2003; DALE, 1994, entre outros), os sistemas privados de ensino inauguram uma estratégia distinta para a presença das corporações junto à esfera pública, pois se trata da contabilização das matrículas como uma espécie de "mercado futuro". (ADRIAO et al, 2015, p. 31)

Segundo este mesmo relatório de pesquisa, em 2014 a Abril Educação anunciou um enorme prejuízo chegando em 2015 a ser vendida a um fundo de investimentos de capital estrangeiro:

No entanto, em 2014, a Abril Educação anunciou um prejuízo líquido de $\mathrm{R} \$$ 18,7 milhões no terceiro trimestre do ano (INFOMONEY, on-line, 11/11/2014). No início de 2015, a Thunnus Participações, administrada pela gestora de fundos Tarpone, detentora desde 2014 de $24 \%$ de suas ações, adquire o grupo19. O "Fato Relevante", documento tornado público nas páginas oficiais da Bolsa de Valores no Brasil no dia 9 de fevereiro de 2015, apresenta a dinâmica do processo que culminaria naquela data com a alteração do controle acionário da empresa...

Segundo este documento, o preço total, considerados contrato e aditivo a ser pago à Abrilpar, foi $R \$$ 1.309.489.668,67, o equivalente, em dólares no período, a cerca de US\$436,5 milhões (ADRIAO et al, 2015, p. 36-37) 


\section{2 - Revista Veja}

A Revista Veja foi criada em 1968 pelos jornalistas Roberto Civita e Mino Carta. A ideia era criar uma revista semanal no modelo da Revista americana Times. No sítio eletrônico que trata sobre a revista Veja se destaca a missão da revista encontrada nos escritos de Roberto Civita:

Ser a maior e mais respeitada revista do Brasil. Ser a principal publicação brasileira em todos os sentidos. Não apenas em circulação, faturamento publicitário, assinantes, qualidade, competência jornalística, mas também em sua insistência na necessidade de consertar, reformular, repensar e reformar o Brasil. Essa é a missão da revista. Ela existe para que os leitores entendam melhor o mundo em que vivemos. (CIVITA, 2015)

Além desta afirmação, consta ainda no corpo dessa página a perspectiva institucional que o grupo Abril espelha para a revista Veja:

Mais do que descrever os fatos, VEJA faz jornalismo por meio da busca da informação inédita e da reflexão original, com o compromisso de filtrar, avaliar e interpretar o noticiário. Através de uma linguagem direta, o conteúdo de VEJA busca informar, esclarecer, entreter, gerar reflexão, enriquecer a vida pessoal e profissional do leitor e ampliar sua compreensão do Brasil e do mundo. Os jornalistas de VEJA não se limitam ao conforto da imparcialidade e travam diariamente um debate intelectual com seus leitores, caracterizando uma marca sólida assentada em uma maneira de ver o mundo. (ABRIL, 2015)

$\mathrm{Na}$ edição número 2.128 da Revista Veja, publicada em 2009, aparece uma reportagem que apresenta um projeto do Grupo Abril: Educar para Crescer. Nesta reportagem destaca-se a produção e distribuição de cartilhas com conteúdos voltados para educação familiar e empresarial. Segundo a reportagem o projeto Educar para Crescer foi o responsável pela produção de três tipos de cartilhas com conteúdos sobre educação. Duas cartilhas seriam destinadas às famílias e uma ao empresariado. As cartilhas 
destinadas às famílias seriam encartadas junto a outras revistas do Grupo Abril (ANA MARIA, VIVA!MAIS, CLAUDIA e a própria VEJA) e distribuídas gratuitamente para quem adquirisse as revistas. Segundo a reportagem o material apresentado nas cartilhas que se destinam as famílias:

Apresenta medidas bem concretas que adotadas pela família, são decisivas para o bom desempenho do estudante. Há duas versões da cartilha: uma dedicada a pais com filhos em escolas públicas, outra direcionada aos que frequentam colégios particulares. Ambas ressaltam como a família pode - e deve - incentivar a leitura, incluir os assuntos escolares nas conversas e zelar pelo essencial: lição de casa sempre feita, lugar adequado para os estudos e presença na sala de aula. O que distingue as duas publicações, basicamente, é que aquela destinada à escola pública enfatiza a importância do Ideb. (VEJA, 2009, p. 108)

Ainda, segundo a reportagem, a cartilha destinada aos empresários viria junto com a edição subseqüente da revista EXAME, veiculada também pelo grupo Abril:

Há ainda uma terceira cartilha, esta para os empresários, que sairá com a próxima edição de EXAME (serão 220.00 exemplares). Ela mostra, com base em exemplos, como é possível incentivar a educação também no ambiente corporativo.

Foram impressos ao todo 6,2 milhões - dos quais 3,6 milhões serão distribuídos por empresas que firmaram parceria com o Educar para Crescer, como McDonalds, Itaú e a malharia Malwee. Outras quinze já sinalizaram interesse em participar do projeto, que não tem fins lucrativos. (VEJA, 2009, p. 108)

A partir do acesso a esta reportagem considerou-se necessário buscar informações sobre o projeto Educar para Crescer, já que o mesmo destina cartilhas gratuitamente aos assinantes da Veja sobre a temática Educação. O projeto foi criado em 2008 "com o intuito de estimular debates e boas práticas relacionadas à educação". No sitio oficial da internet sobre o projeto aparece a informação de que o: 
Educar para Crescer é um movimento de longo prazo e sem fins lucrativos que conta com o apoio do Ministério da Educação e com a força de comunicação do Grupo Abril para estimular boas práticas e destacar a importância da Educação para o crescimento do Brasil e de seus cidadãos. (EDUCAR PARA CRESCER, 2015)

Já no endereço eletrônico do Grupo Abril o projeto Educar para Crescer é também destaque:

O progresso da educação está na missão do Grupo Abril que, por meio de suas empresas, contribui para a melhoria do ensino no país. O Educar para Crescer foi criado para ampliar o impacto das iniciativas de educação do Grupo e para tornar esse tema uma grande pauta nacional.

É um movimento de longo prazo e sem fins lucrativos que conta com o apoio do Ministério da Educação e com a força de comunicação do Grupo Abril para estimular boas práticas e destacar a importância da educação para o crescimento do Brasil e dos seus cidadãos. (ABRIL, 2015)

Outro dado importante referente ao Educar para Crescer se encontra quando se entra no endereço eletrônico deste movimento e nota-se que no centro da página em destaque aparecem quatro notícias numeradas de 1 a 4 que podem ser acessadas com um clique em cima da reportagem que se deseja ler. Durante meu acesso efetuado no dia 14/05 de 2016 às 14:30 aproximadamente, a primeira notícia que apareceu como opção de leitura era de uma reportagem da revista Exame (pertencente ao Grupo Abril) com o título: O que Singapura pode nos ensinar? Acima do título estava escrito apenas em letras maiúsculas duas palavras que indicavam o tema em discussão nessa reportagem: REFORMA EDUCACIONAL.

Esta reportagem tem data de publicação na página eletrônica Educar para Crescer de 04 de maio de 2016. O conteúdo desta notícia contempla as reformas educacionais que aconteceram em Singapura e que, segundo interpretação do repórter que assina a matéria, contribuíram para a melhora nos índices de avaliações externas, especialmente o PISA (Programa Internacional de Avaliação de Aluno). Destaque-se no texto a ênfase no sistema 
de premiação ao mérito dos docentes que alcançam bons resultados nas avaliações externas, assim como a punição daqueles que não atingem o objetivo esperado nesses nos testes. Segundo o texto:

Singapura aplicou esse sistema em moldes meritocráticos extremamente rígidos. Por lá, professores são anualmente testados e, identificados os talentos, ganham promoções. Os melhores e mais interessados viram gestores educacionais, enquanto os que se saem mal sucessivamente são demitidos. (EDUCAR PARA CRESCER, 2016)

Corroborando com as ideias destacadas pelo repórter que assina a matéria, dois sujeitos são evocados ao longo do texto com suas opiniões. O primeiro deles é Lee Sing Kong, ex-diretor do Instituto Nacional de Educação de Singapura, o responsável pela reforma educacional apresentado no texto. $\mathrm{O}$ ex-diretor, quando se remete a realidade da educação no Brasil, afirma:

Dentro de cada escola, há uma variação enorme entre as práticas do melhor para o pior professor. O positivo disso é que já existe uma maior possibilidade de difusão de boas práticas dentro das escolas. O problema é que todos são tratados da mesma forma, mesmo aqueles com desempenho muito diferenciado. Os bons não recebem incentivo, os ruins não sofrem consequências. (EDUCAR PARA CRESCER, 2016)

O segundo sujeito apresentado no texto pertence ao Banco Mundial. Trata-se da economista-chefe da instituição na área de educação para América Latina e o Caribe, Barbara Bruns. Segundo o texto, a solução indicada por Barbara para o Brasil aborda:

Políticas públicas mais exigentes, que eliminem os professores com baixo desempenho e dê bônus aos excelentes através de avaliações periódicas auditadas por instituições externas ao governo, como acompanhamento de aulas e supervisão da evolução didática dos alunos. Um modelo muito próximo ao de Singapura. (EDUCAR PARA CRESCER, 2016) 
Ainda, no texto se encontra a comparação do percentual do PIB gasto em educação em Singapura (3,7\%), em contraste com o Brasil que, segundo a reportagem, tem sindicatos ligados à educação que pedem 10\% do PIB. Logo após essa comparação, é apresentada outra citação de Lee Sing Kong que justifica outros modelos de reconhecimento profissional para além da remuneração:

Há muitas maneiras de se reconhecer o bom trabalho dos professores além da remuneração. É claro que é importante, mas outras iniciativas como celebrar esse trabalho e reconhecer de forma pública a contribuição daquele professor para o futuro faz com que ele se sinta reconhecido. (EDUCAR PARA CRESCER, 2016)

\section{3 - Os articuladores do tema Educação e gestão escolar na revista Veja}

Segundo o levantamento de dados feito para este relatório dois sujeitos se destacam entre aqueles que publicam na Revista Veja sobre a temática Gestão Escolar. São eles, Gustavo loschpe e Cláudio Moura Castro. Para chegar a estabelecer este critério temático sobre as publicações, primeiro foram levantados todos os conteúdos da revista que tratavam do tema educação e seus respectivos autores. Posteriormente, realizou-se um filtro em que foram selecionados para análise apenas aquelas publicações que abordavam o tema gestão escolar. É sobre este tema que Cláudio Moura e Gustavo loschpe se destacam nas publicações.

O gráfico abaixo isola apenas os articulistas que tiveram publicações na revista Veja ao longo do tempo pesquisado (reportagens e entrevistas não entram aqui) e demonstra a participação dos autores acima mencionados em relação a todos os articulistas que publicaram na revista ao longo de todos os anos de publicações levantados. 


\section{Artigos sobre gestão escolar e inserção por Autor na Revista Veja no período de 1997-2014}

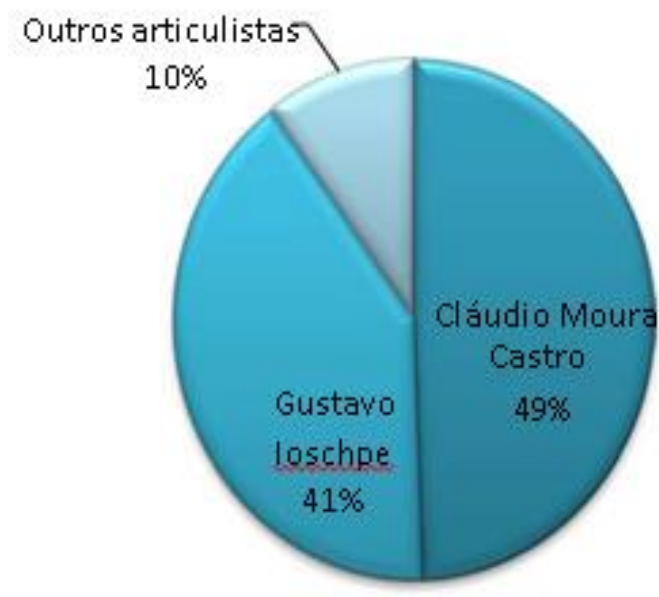

Fonte: Autor a partir de consultas a 936 ediçổes da revista Veja

Nesse sentido é importante discorrer um pouco sobre a trajetória de cada um, assim como suas participações no campo educacional.

Cláudio de Moura Castro formou-se em Economia pela Universidade Federal de Minas Gerais (UFMG) em 1962. Fez pós-graduação em Economia pela Fundação Getúlio Vargas (Rio de Janeiro) no ano de 1963. Seu mestrado se deu pela Universidade de Yale nos Estados Unidos no ano de 1964. Participou de cursos de Filosofia e Desenvolvimento Político pela Universidade de Harvard em 1965. Tornou-se Doutor em Economia pela Universidade de Berkeley na Califórnia no ano de 1965. Em 1970 obteve o Ph.D. em Economia na Universidade de Vanderbilt ainda nos Estados Unidos. Importante ressaltar que a maior parte de suas pesquisas estão ligadas à área educacional, sendo um economista sempre muito preocupado com a temática educação, especialmente ensino superior, educação e gestão escolar.

Em sua atuação profissional ensinou nos programas de mestrado da PUC/Rio, Fundação Getúlio Vargas, Universidade de Chicago, Universidade de Brasília, Universidade de Genebra e Universidade da Borgonha em Dijon. Trabalhou no Instituto de Pesquisa em Saúde (INPES/IPEA). Em seguida foi diretor geral da Coordenação de Aperfeiçoamento de Pessoal de Nível Superior (CAPES). Foi também Secretario Executivo do CNRH/IPEA. No 
exterior, foi Chefe da Divisão de Políticas de Formação da OIT (Organização Internacional do Trabalho) em Genebra, Economista Sênior de Recursos Humanos do Banco Mundial, passando para o BID (Banco Interamericano de Desenvolvimento) como Chefe da Divisão de Programas Sociais. Ao aposentar-se do BID, assumiu a posição de Presidente do Conselho Consultivo da Faculdade Pitágoras. Também é assessor especial da Presidência do Grupo Positivo. É colunista da revista Veja desde 1996. Estas informações estão disponíveis no próprio sítio eletrônico do autor

Além disso, também atua ou atuou como membro em diversos conselhos de entidades privadas. É conselheiro na Fundação Victor Civita. Também atua como conselheiro no Instituto Unibanco. Já foi membro do Conselho Consultivo da revista Conjuntura Social publicada pelo Instituto Ayrton Senna, assim como atuou como membro do Conselho Consultivo da Rede Globo para preparar programas educacionais em comemoração aos 500 anos do Brasil. Destaca-se também participação como membro do Comitê de Educação da Fundação Ford no Brasil ainda na década de 1970 em que fez parte de 1971 até 1978. Ainda, como membro do Comitê de Educação da Fundação Ford participava da seleção de projetos em Israel (1976-1979).

Ainda no sitio de Claudio Moura Castro aparecem muitas informações sobre participações dele como membro em Conselhos de diversas Ongs. Porém algumas não informam período que ele esteve à frente da Ong ou se ainda é membro. Por exemplo, aparece que ele foi membro do Conselho Consultivo do Instituto Sangari. Porém, este instituto não existe mais, ao que tudo indica deu origem a outro de nome abramundo (escrito assim mesmo com letras minúsculas) que tem no seu Conselho de Apoio Técnico e Cientifico Guiomar Namo de Mello e Simon Schwartzman. Além disso, Cláudio Moura Castro é Conselheiro do Instituto Unibanco.

Cláudio Moura Castro também é integrante da Comissão Externa de Avaliação (CEA) do Insper (Instituição de Ensino e Pesquisa, sem fins lucrativos, nas áreas de administração, economia, direito e engenharia). Em 2014 o Insper contratou o docente Ricardo Paes de Barros com uma cátedra patrocinada pelo Instituto Ayrton Senna (IAS). Ricardo também coordena o Núcleo de Ciência pela Educação, integrado ao Centro de Políticas Públicas. A Cátedra Instituto Ayrton Senna foi criada em março de 2015 e tem por objetivo principal 
fomentar o desenvolvimento de estudos e pesquisas que sirvam como base de dados empíricos para a criação de políticas públicas na área de educação.

O outro articulista que também publica com muita frequência na revista Veja sobre o tema gestão escoar é o Gustavo loschpe. Formado na Universidade da Pensilvania dos Estados Unidos em strategic management (B.S., Wharton School), Ciência Política (B.A., College of Arts and Sciences). Mestre em Desenvolvimento Econômico e Economia Internacional pela Universidade de Yale dos Estados Unidos. Articulsita da revista Veja (desde 2006) e colunista da Folha de São Paulo (1996-2000 e 2006). Vencedor do Prêmio Jabuti 2005 pelo livro "A Ignorância Custa um Mundo". Fundador e CEO da empresa Big Data, empresa pioneira da área de big data analythics no Brasil. Membro dos conselhos de administração da loschpe-Maxion e Instituto Ayrton Senna. Também faz parte do Conselho curador da Fundação loschpe. Foi um dos signatários e membros fundadores do Todos Pela Educação. Além disso, é membro do Conselho de Administração do Grupo RBS (afiliada da TV Globo e transmitida no Sul do país).

Gustavo loschpe participou do especial "Blitz da Educação", promovido pelo Jornal Nacional da Rede Globo, em maio de 2011 e foi o especialista em educação convidado para acompanhar a série de reportagens desse especial do Jornal Nacional. Uma sequência de cinco programas do Jornal que visitou 10 escolas do Brasil em cinco municípios diferentes.

Assim como Cláudio Moura Castro, Gustavo loschpe também é integrante da Comissão Externa de Avaliação (CEA) do Insper (Instituição de Ensino e Pesquisa, sem fins lucrativos, nas áreas de administração, economia, direito e engenharia). Além disso, Gustavo loschpe é um dos especialistas presentes e que tem artigos veiculados pelo Instituto Millenium. Este instituto tem entre seus mantenedores João Roberto Marinho, Armínio Fraga, Ricardo Diniz, Jorge Gerdau, Giancarlo Civita (Um dos conselheiros da Fundação Victor Civita). Segundo o sítio eletrônico do Instituto - "o Insituto Millenium (Imil) é uma entidade sem fins lucrativos e sem vinculação político-partidária com sede no Rio de Janeiro. Formado por intelectuais e empresários, o think tank promove valores e princípios que garantem uma sociedade livre, com liberdade individual, direito de propriedade, economia de mercado, democracia representativa, Estado de Direito e limites institucionais à ação do governo". 
Importante ressaltar participações que Gustavo loschpe e Cláudio Moura Castro têm em Fóruns que tratam do tema Educação. Por exemplo, o evento Fóruns Estadão Brasil 2018 realizado em 2014, tratou de discutir vários temas, entre eles Educação. Esse evento teve como parceiro acadêmico o Insper e contou com a presença de Gustavo loschpe. Outro exemplo de evento com maior repercussão é o Fórum Nacional de Educação que teve sua primeira edição em 2014 e contou com a presença do então ministro da Educação Henrique Paim, o Governador de São Paulo, Geraldo Alckmin, Prefeito de São Paulo, Fernando Haddad, secretário de Educação do Estado de São Paulo, Herman Jacobus Voorwald, além de muitos outros sujeitos, dentre eles, Gustavo loschpe e Cláudio Moura Castro.

Faz-se necessário destacar que embora o evento se chame Fórum Nacional de Educação, ele é organizado pelo LIDE - Grupo de Líderes Empresarias, comandado por João Dória Júnior. O evento foi promovido pelo LIDE EDUCAÇÃO, presidido por Osmar Zogbi e o Instituto Ayrton Senna, presidido por Viviane Senna, e teve como tema central "Educação e Competitividade". Além disso, o evento premia empresas e empresários que segundo a organização do LIDE EDUCAÇÃO "reconhecem a educação como chave para a produtividade, como Nestlé, Cielo, P\&G, Integration e Morpho Cards".

Nesse sentido, embora o nome do evento transpareça a ideia de um fórum em que todos os atores da educação do país estejam envolvidos, aparentemente é um evento do setor privado para dialogar com o setor privado e também os representantes do executivo da educação pública, como iniciativa de influenciar em políticas públicas.

Dessa forma, embora o Fórum seja nacional, ele é organizado e pautado por demandas do setor privado. Ele contempla os atores do mais alto escalão das execuções de políticas publicas para educação. E versa sobre perspectivas e estratégias para toda educação do país.

Interessante notar também que ambos, Gustavo loschpe Cláudio Moura Castro, já participaram como quadros de colaboradores do Instituto Ayrton Senna, que estava participando da organização do Fórum Nacional da Educação, e convidou os dois articulistas da Revista Veja para palestrarem sobre educação pública em tal evento.

Como informado acima, a família loschpe também tem uma Fundação (Fundação loschpe) da qual Gustavo faz parte. Segundo a informação disponível no sitio oficial da 
fundação, esta foi criada para atuar no campo da educação. Conforme consta neste endereço eletrônico a Fundação loschpe:

Foi criada em 1989 pela loschpe-Maxion S/A - grupo empresarial que opera nos segmentos de autopeças e equipamentos ferroviários - a Fundação desenvolve programas nas áreas de Educação Profissional e Arte-Educação realizando parcerias com entidades públicas e privadas. A prioridade é o atendimento a jovens e crianças beneficiando mais de 25 mil pessoas por ano em 22 estados brasileiros. (FUNDAÇÃO IOSCHPE, 2015)

Dentre os programas criados pela Fundação destaca-se o Formare. Este programa foi criado em 1995 quando a Fundação assume o Projeto Escolas Técnicas loschpe-Maxion e firma acordo pedagógico com o Centro Federal de Educação Tecnológica do Paraná (CFETPR). O programa Formare também apresenta um sítio eletrônico especifico para consulta - www.formare.org.br - e no tópico institucional sobre o que é o Formare, está disponível a seguinte informação:

O Formare é um programa da Fundação lochpe que, a partir de parcerias com empresas de médio e grande portes, oferece cursos de educação profissional $^{\star}$ (ou ensino profissionalizante) para jovens a partir de 16 anos de famílias em situação de vulnerabilidade social.

Os cursos proporcionam a oportunidade de formação inicial para o mundo do trabalho e têm a duração de aproximadamente um ano. As aulas são ministradas pelos próprios funcionários nas instalações da empresa. (FORMARE, 2015)

Destaque para a presença de Maria Helena Guimarães de Castro (ex-secretária da educação do Estado de São Paulo) no Conselho curador da Fundação loschpe. Enquanto secretária da educação do Estado de São Paulo Maria Helena concedeu entrevista à revista Veja nas páginas amarelas e sua entrevista é objeto de análise posteriormente neste trabalho.

Este trabalho pretende realizar para a defesa uma rede de ligações entre sujeitos e instituições que dialogam com o Grupo Abril, a Revista Veja, os principais articulistas da 
Revista e os sujeitos entrevistados nas páginas amarelas. Este movimento tem o intuito de construir uma rede que amplie a visão em torno das relações que a Revista Veja tem com os mais diversos sujeitos e instituições. 


\section{3 - REVISTA VEJA E A EDUCAÇÃO: DEZOITO ANOS DE PUBLICAÇÕES E DOIS MOMENTOS BEM DISTINTOS}

Foram consultadas 936 edições nesses 18 anos de publicações (1997-2014). Dentre as publicações levantadas estão artigos, reportagens e entrevistas nas páginas amarelas. Para realizar a pesquisa foi utilizado o acervo digital da Revista Veja. O movimento de pesquisa inicial foi verificar edição por edição em busca de conteúdos publicados sobre educação. Neste sentido, foram verificados as reportagens, artigos e entrevistas nas páginas amarelas que apareceram no corpo da revista desde janeiro de 1997 até dezembro de 2014. Assim, pude identificar e selecionar quais destas publicações tratavam do tema educação. São 452 edições que apresentam uma ou mais publicações sobre o tema educação. Isso é quase metade do total de edições desse período.

\section{Edições da Revista Veja com publicações sobre o tema educação (1997-2014)}

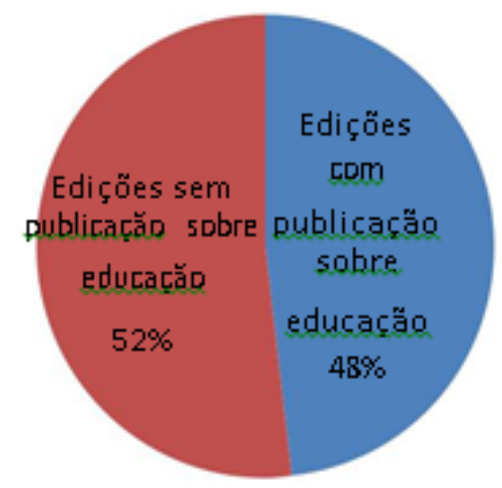

Fonte: Autor a partir de consultas a 936 ediçỗes da revista Veja dos anos de 1997 a 2014

Se levarmos em conta que algumas vezes uma mesma edição apresentou mais de uma publicação sobre educação, teremos um total de 578 publicações sobre esse tema. Entretanto, o foco da pesquisa se dá nas publicações sobre gestão escolar. Para isso, novas leituras sobre o material coletado foram necessárias para delimitar quais inserções tratavam do tema gestão escolar. É claro que na pré-análise, como Bardin descreveu, já 
havia o movimento de transformar alguns dados em unidades de registro e contexto. Pois alguns textos estavam claros que tratavam sobre gestão escolar, como na reportagem da edição 1995 de 14 de fevereiro de 2007 p. 94-95, com o título "Escola pública, Gestão particular". No entanto, algumas publicações precisavam de mais de uma leitura e movimentos de aprofundamento para desvelar o conteúdo sobre gestão escolar. Após a nova releitura e codificação dos dados, chegou-se ao número de 169 publicações sobre gestão escolar ao longo dos 18 anos de edições da revista Veja analisados. Esse número representa aproximadamente $29 \%$ do total de conteúdos sobre educação. Ou seja, dentro do universo total de aparições de conteúdos sobre educação, 29\% abordavam a temática gestão escolar e os restantes $71 \%$ não.

\section{Publicações Revista Veja em educação (1997-2014)}

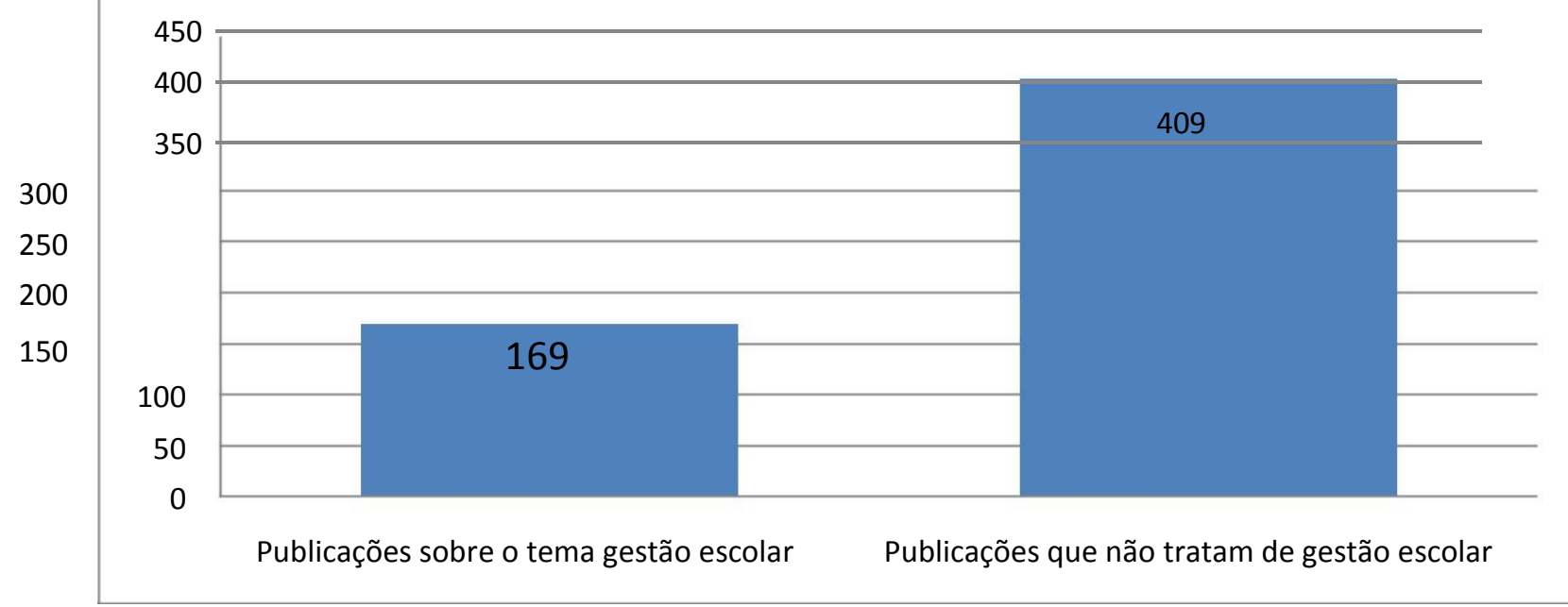

Fonte: Autor após levantamento da quantidade total de publicações sobre educação

É importante ressaltar que pela pesquisa feita é possível e até adequado separar o recorte temporal em dois períodos de publicação: 
- 1997-2005: Neste período de nove anos foram levantadas 198 publicações sobre a temática educação, das quais $23(11 \%)$ tratavam sobre gestão escolar.

- 2006-2014: Neste período de nove anos foram levantadas 380 publicações sobre a temática educação, das quais 146 (38\%) tratavam sobre gestão escolar.

É necessário informar que o recorte entre períodos não é somente por dividirem os dois em quantidades de anos iguais. Chegou-se a este movimento por conta do que os dados mostraram. Como visto de 1997 até 2005 o percentual de publicação sobre gestão escolar foi de apenas $11 \%$. No ano de 2005 especificamente a média foi muito parecida, ficando em 12\% de conteúdos que aparecem sobre gestão escolar. É, pois, em 2006 que esta porcentagem aumenta sensivelmente. De 19 publicações sobre educação em 2006, seis eram sobre gestão escolar (31\%). Percentual quase três vezes maior que o apresentado no ano de 2005.

Quanto aos dados do recorte temporal percebe-se claramente uma diferença entre quantidades de publicações quando comparados os dois períodos. De 2006 até 2014 o volume de inserções sobre educação quase dobrou em relação ao período anterior (972005). Além disso, outra comparação relevante entre os dois momentos temporais é em relação às publicações sobre gestão escolar. No período de 2006 a 2014 o volume de conteúdos sobre gestão é seis vezes maior do que aquele encontrado entre os anos de 1997 até 2005. Esta diferença editorial por publicar mais sobre educação e ainda mais sobre gestão escolar elenca questões sobre o porquê desta frequência maior em tratar destes temas e desvela hipóteses sobre quais são as motivações que levam a revista a esta escolha editorial. Uma das várias hipóteses seria a fundação do movimento Todos pela Educação que ocorre justamente em 2006. Dentre os vários signatários fundadores está Gustavo loschpe que coincidentemente começa a escrever na revista Veja nesse mesmo ano. Ademais, é o próprio loschpe em seu primeiro artigo escrito para a revista, que destaca a importância dos economistas e empresários para revolucionarem a educação pública: "Apesar da resistência que educadores e pedagogos têm à intromissão de economistas, empresários e afins, em seu território, é neles que se encontrará a revolução educacional 
que o país necessita". (edição 1971 de 30 de agosto de 2006, p. 104-105) - Importante destacar aqui que o trabalho posteriormente pretende aprofundar os fatores contextuais que levaram a essa mudança editorial da revista sobre a quantidade de publicações sobre educação e, especificamente, gestão escolar. Por exemplo, 2005 foi o ano limite para os entes federados se adaptarem à lei de responsabilidade fiscal.

Dando sequência a apresentação dos dados, após identificar quais eram as publicações que tratavam sobre gestão escolar, o movimento de pesquisa posterior foi de dividir as publicações sobre gestão especificamente por tipo de inserção na revista. São três as formas analisadas: Entrevistas, artigos e reportagens. Nesse sentido, o gráfico abaixo retrata a proporção de aparição de cada uma dessas formas.

\section{Publicações na Revista Veja sobre o tema gestão escolar por tipo de inserção}

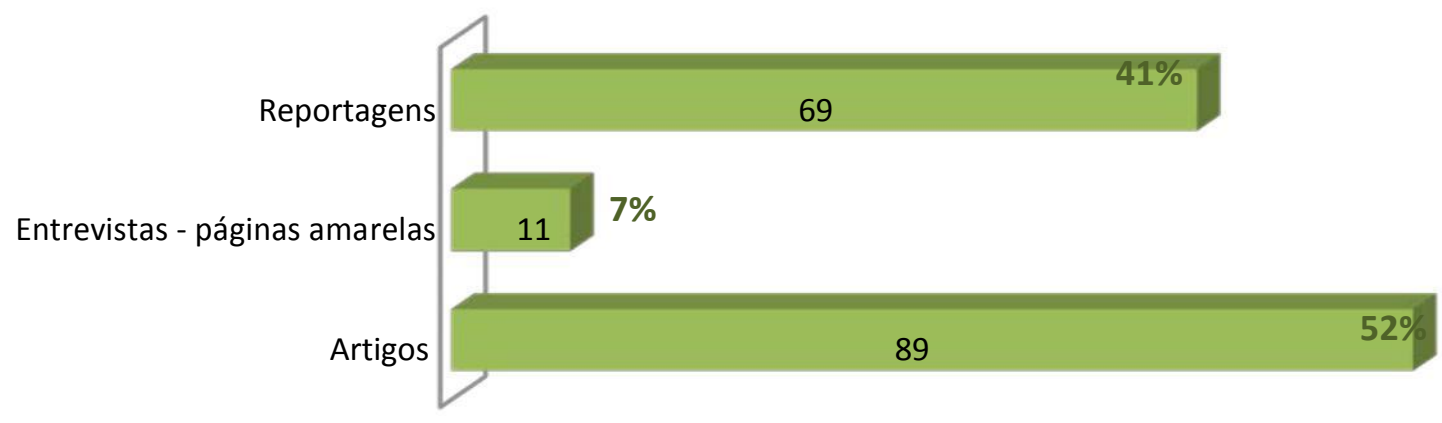

Fonte: Autor do texto pela consulta de 169 publicações que tratavam do tem gestão escolar

Como se pode notar o maior número de conteúdos publicados na revista Veja sobre gestão escolar são oriundos de artigos e reportagens. Destes, os artigos apresentam maior número de publicações com menor número de sujeitos que publicam. A quantidade de pessoas que escrevem reportagens é bem maior. São 21 ao todo ao longo dos 18 anos de levantamento. Dos articulistas que escrevem sobre gestão escolar dois se destacam: Cláudio Moura Castro e Gustavo loschpe. Além deles, outros articulistas também apresentaram em algum momento artigos que abordavam o tema gestão escolar. São eles: Stephen Kanitz, Lya Luft, Reinaldo Azevedo e Roberto Civita. Contudo, a maioria dos artigos sobre gestão escolar é predominante nas figuras de Cláudio Moura Castro e Gustavo loschpe. 


\section{Artigos sobre gestão escolar e inserção por Autor na Revista Veja no período de 1997-2014}

Outros articulistas

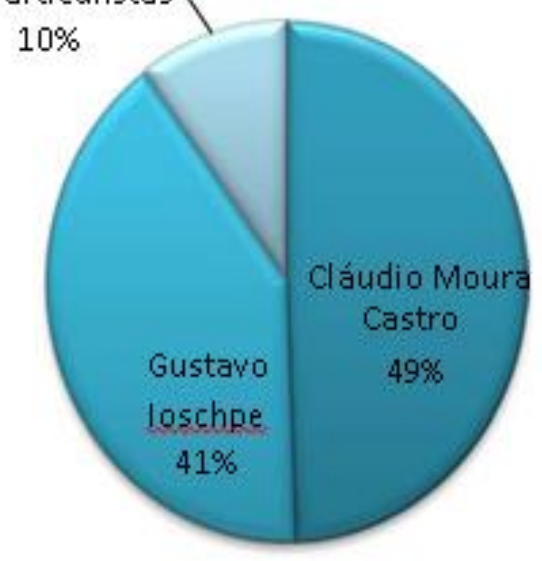

Fonte: Autor a partir de consultas a 936 ediçốes da revista Veja

Como já exposto até o ano de 2006 Gustavo loschpe ainda não escrevia na revista. Nesse sentido, se compararmos proporcionalmente as publicações dos autores e dividirmos pelos dezoito anos de recorte temporal da pesquisa, loschpe aparecerá com uma proporção maior de publicação por ano. Entretanto, o mesmo movimento que acomete o editorial da revista Veja a partir de 2006, acontece com Cláudio Moura Castro que, embora até 2005 se destacasse como sujeito com mais publicações sobre gestão escolar, foi aumentando seu percentual de publicações sobre o tema ao longo dos anos. - Aqui tratarei de caracterizar melhor os articulistas posteriormente.

\section{1 - Categorias de análise referentes ao tema gestão escolar}

Depois de levantar a quantidade de publicações sobre gestão escolar, separar os conteúdos entre artigos, reportagens e entrevistas e destacar quais os articulistas que mais publicam, o próximo movimento necessário de pesquisa foi de codificar os conteúdos em unidades de contexto menores e mais especificas e categoriza-los em temáticas 
relacionadas à gestão escolar. Os temas levantados e codificados são condizentes àqueles que foram encontrados no corpo dos textos e conteúdos publicados.

Outra perspectiva em relação a este movimento de pesquisa foi o de verificar quais temas relacionados à gestão escolar apareceram com mais freqüência, mensurando quantidade de aparição por ano. Para isso, foram divididos os conteúdos analisados em quatro grandes temáticas que se referem ao campo de análise da temática gestão escolar. Nesse sentido, as categorias de análise temáticas mais recorrentes foram:
a) Administração Gerencial
b) Avaliações Externas
c) Terceiro Setor e/ou Parceria Público Privado
d) Diretor Escolar

\section{A) Administração Gerencial}

A administração gerencial é um conceito que caracterizou e influenciou reformas em vários Estados Nacionais de maneira hegemônica, incluindo o Brasil, notadamente a partir dos anos 90. Assim, sua lógica também está presente nos debates e diretrizes que norteiam a educação pública, com exemplos em todas as esferas da federação. Nesse sentido, a revista Veja como formadora de opinião e exemplo de mídia veiculada nacionalmente, se insere nesse campo de debate apresentando muitos conteúdos acerca deste tema.

O conceito da administração gerencial é cada vez mais presente nas administrações públicas. Segundo Paula, 2005: 
A origem da vertente da qual deriva a administração pública gerencial brasileira está ligada ao intenso debate sobre a crise de governabilidade e credibilidade do Estado na América Latina durante as décadas de 1980 e 1990. Esse debate se situa no contexto do movimento internacional de reforma do aparelho do Estado, que teve início na Europa e nos Estados Unidos. Para uma melhor compreensão desse movimento, é preciso levar em consideração que ele está relacionado com o gerencialismo, ideário que floresceu durante os governos de Margareth Thatcher e de Ronald Reagan. (PAULA, 2005, p. 37)

Bresser Pereira em seu texto, Da administração Pública Burocrática à Gerencial (1996), trata da necessidade, em sua opinião, de se reformar o Estado a partir da lógica gerencial. Para ele, "a crise do Estado implicou na necessidade de reformá-lo e reconstruílo; a globalização tornou imperativa a tarefa de redefinir suas funções." (BRESSER, 1996, p. 1).

O autor traça um paralelo histórico entre a reforma administrativa burocrática que veio para substituir a administração patrimonialista, ainda nos anos 30 no Brasil, e que a administração gerencial deve em várias partes da estrutura do Estado substituir a administração burocrática. Já que na visão do autor, o Estado precisa se modernizar.

Para Junquilho (2010), os servidores e os valores dentro do Estado Gerencial devem ser diferentes daqueles presentes na administração pública burocrática: 
Ao falarmos de Estado Gerencial temos que considerar o perfil dos servidores públicos nesta nova gestão. Para tanto, vamos destacar a posição de Bresser-Pereira (1998b) que define como perfil desejado para os servidores públicos a transformação de "administradores públicos" para "gerentes". Essa proposta é considerada, pelo autor, como a dimensão cultural no Estado Gerencial, pois pressupõe a mudança dos chamados valores burocráticos pelos gerenciais...

Vale destacarmos aqui que os valores gerenciais seriam aqueles advindos do setor empresarial e que, ao migrarem para o setor público, permitiriam a formação de gerentes públicos identificados com a primazia do cliente e do mercado, com a diversidade e a flexibilidade, com as habilidades multidimensionais dos profissionais, com a delegação em lugar do controle, com a ênfase nos resultados e na educação em vez do treinamento e com estruturas organizacionais enxutas e ágeis (OSBORNE; GAEBLER, 1995). (JUNQUILHO, 2010, p. 71)

O ideário da administração gerencial, portanto, tende a transformar o administrador público em um gerente e, como tal, ter maior responsabilidade sobre seus sucessos e fracassos dentro de uma lógica de meritocracia e premiação ao mérito. Ainda segundo Paula acerca das reformas gerenciais que aconteceram no Reino Unido e Estados Unidos nos anos 80:

Em ambos os países, o movimento gerencialista no setor público é baseado na cultura do empreendedorismo, que é um reflexo do capitalismo flexível e se consolidou nas últimas décadas por meio da criação de um código de valores e condutas que orienta a organização das atividades de forma a garantir controle, eficiência e competitividade máximos (Harvey, 1992). (PAULA, 2005, p. 37-38)

Ainda, a mesma autora produz um quadro em que elenca diferenças entre a Administração Pública Gerencial e a Administração Pública Societal. 
Quadro 1 - Variáveis observadas na comparação dos modelos.

\begin{tabular}{|c|c|c|}
\hline & ADMINISTRACAO PUBBLICA GERENCIAL & ADMINISTRACAO PÜBLICA SOCIETAL. \\
\hline Origem & $\begin{array}{l}\text { Movimento internacional pela reforma do } \\
\text { Estado, que se iniciou nos anos } 1980 \text { e se } \\
\text { basela principalmente nos modelos ingles } \\
\text { e estadunidense }\end{array}$ & $\begin{array}{l}\text { Movimentos sociais brasileiros, que tiveram } \\
\text { inicio nos anos } 1960 \text { e desdobramentos } \\
\text { nas trés décadas seguintes }\end{array}$ \\
\hline Projeto politico & $\begin{array}{l}\text { Enfatiza a eficiencia administrativa e se ba- } \\
\text { seia no ajuste estrutural, nas recomenda. } \\
\text { coes dos organismos multilaterais interna- } \\
\text { cionais e no movimento gerencialista. }\end{array}$ & $\begin{array}{l}\text { Enfatiza a participaçáo social e procura es- } \\
\text { truturar um projeto politico que repense } 0 \\
\text { modelo de desenvolvimento brasileiro, a } \\
\text { estrutura do aparelho de Estado e o para- } \\
\text { digma de geståo. }\end{array}$ \\
\hline $\begin{array}{l}\text { Dimensoes estruturais } \\
\text { enfatizadas na geståo }\end{array}$ & $\begin{array}{l}\text { Dimensoes economico-financeira e institu- } \\
\text { cional-administrativa }\end{array}$ & Dimensão sociopolitica \\
\hline $\begin{array}{l}\text { Organizaçào administrativa } \\
\text { do aparelho do Estado }\end{array}$ & $\begin{array}{l}\text { Separaçao entre as atividades exclusivas e } \\
\text { nåo-exclusivas do Estado nos trés niveis go- } \\
\text { vernamentais }\end{array}$ & $\begin{array}{l}\text { Náo há uma proposta para a organizaçáo } \\
\text { do aparetho do Estado e enfatiza iniclativas } \\
\text { locais de organizaçáo e gestáo pública }\end{array}$ \\
\hline $\begin{array}{l}\text { Abertura das instituiçoes } \\
\text { politicas à participaçáo social }\end{array}$ & $\begin{array}{l}\text { Participativo no nivel do discurso, mas } \\
\text { centralizador no que se refere ao processo } \\
\text { decisorio, a organizaça das instituiçoes } \\
\text { politicas e à construçào de canais de par- } \\
\text { ticipaçá popular }\end{array}$ & $\begin{array}{l}\text { Participativo no nivel das instituiçoes, en- } \\
\text { fatizando a elaboraçăo de estruturas e ca- } \\
\text { nais que viabilizem a participaçăo popular }\end{array}$ \\
\hline Abordagem de gestão & $\begin{array}{l}\text { Gerencialismo: enfatiza a adaptaçáo das } \\
\text { recomendaçoes gerencialistas para o se- } \\
\text { tor público }\end{array}$ & $\begin{array}{l}\text { Gestão social: enfatiza a elaboraçáo de ex- } \\
\text { periências de geståo focalizadas nas de- } \\
\text { mandas do publico-alvo, incluindo ques- } \\
\text { toes culturais e participativas }\end{array}$ \\
\hline
\end{tabular}

PAULA, 2005, p. 41

Enquanto a Administração Pública Gerencial está estruturada nas dimensões econômico-financeira e institucional-administrativa, a Administração Pública Societal é estruturada na dimensão sociopolítica. Este fato é relevante no sentido em que, os dados desta pesquisa sobre a revista Veja, apontam uma defesa incessante na transposição dos valores gerenciais para a educação pública. Também é importante notar que a maioria 
daqueles que tergiversam sobre educação na revista advém do campo da Economia. Fato consonante com a dimensão estrutural da Administração Pública Gerencial. A questão que fica é: uma educação pública que pretende atender os anseios de emancipação humana e desenvolvimento de uma sociedade inteira pode estar centrada em aspectos estruturais cujas dimensões de atuação são basicamente econômicas/financeiras e institucionais administrativas?

Para identificar a temática administração gerencial nos conteúdos da revista foram consideradas as seguintes expressões e/ou ideias temáticas especificas:

- Meritocracia

- Eficácia e eficiência

- Escolas organizadas como uma boa empresa

- Premiar o mérito, bônus.

Além das expressões acima, mais propriamente vinculadas à administração gerencial, também foram a elas associadas as referências a correntes clássicas do pensamento empresarial como Taylorismo, Fordismo, pois apareceram na discussão sobre o modelo gerencial, além da própria gestão de qualidade total.

Segue a tabela 1 sobre a temática Administração Gerencial. 
Tabela 1 - Referências em quantidade de vezes às expressões vinculadas à Administração Gerencial (Meritocracia, Eficácia e eficiência, Escolas organizadas como uma boa empresa, Premiar o Mérito, bônus) presentes em artigos, entrevistas e reportagens selecionados na revista Veja entre 1997 até 2014

\begin{tabular}{|c|c|c|c|c|}
\hline TEMA & \multicolumn{4}{|c|}{ TIPO DE PUBLICAÇÃO } \\
\hline Administração & & & & TOTAL \\
\hline Gerencial & ARTIGOS & ENTREVISTAS & REPORTAGENS & ANO \\
\hline 1997 & & & 1 & 1 \\
\hline 1998 & 2 & & 2 & 4 \\
\hline 1999 & 1 & & 1 & 2 \\
\hline 2000 & 2 & & 2 & 4 \\
\hline 2001 & 3 & & 2 & 5 \\
\hline 2002 & 2 & & & 2 \\
\hline 2003 & 3 & & 1 & 4 \\
\hline 2004 & 4 & & 2 & 6 \\
\hline 2005 & 2 & & 2 & 4 \\
\hline 2006 & 5 & 1 & 3 & 9 \\
\hline 2007 & 7 & 1 & 6 & 14 \\
\hline 2008 & 6 & 2 & 4 & 12 \\
\hline 2009 & 6 & 1 & 4 & 11 \\
\hline 2010 & 7 & 1 & 5 & 13 \\
\hline 2011 & 8 & 1 & 7 & 16 \\
\hline 2012 & 10 & 1 & 4 & 15 \\
\hline 2013 & 9 & 2 & 6 & 17 \\
\hline 2014 & 8 & 1 & 4 & 13 \\
\hline TOTAL & 85 & 11 & 56 & 152 \\
\hline
\end{tabular}

Necessário destacar que em quase todas as publicações sobre gestão escolar 0 conceito de administração gerencial está presente, por se tratar de um conceito que abrange os conteúdos de gestão escolar presentes no setor privado. Por exemplo, em uma publicação pode aparecer a expressão premiar o mérito. Esta dimensão meritocrática vem 
sempre acompanhada de outro tema: por exemplo, avaliações externas que pretendem identificar o que é mérito sob uma determinada perspectiva.

\section{B) Avaliações externas}

Outra categoria de análise muito recorrente nos conteúdos levantados foi avaliação. Essa categoria é bem recorrente nos conteúdos sobre gestão escolar como instrumento de aferição da qualidade da educação. Avaliações externas e resultados publicados pelo Ministério da Educação (MEC) e Organização para Cooperação e Desenvolvimento Econômico (OCDE) são recorrentes para legitimar posicionamentos da revista Veja sobre educação de qualidade e escolas de qualidade. Necessário pontuar que as avaliações externas apontadas são aquelas em larga escala feitas para avaliar uma rede de ensino, estudantes de um país e do mundo. É uma categoria que ao longo dos anos é cada vez mais utilizada seja em reportagens, artigos ou mesmo entrevistas. Tópicos e palavras que nortearam a construção dessa categoria:

- Avaliações de desempenho

- Ranqueamentos

- Centralidade dos resultados em testes internacionais/nacionais

- MEC, OCDE, PISA

Abaixo segue a tabela com os dados coletados da temática especifica sobre avaliações externas nos dezoito anos de publicações analisados:

Tabela 2 - Referências em quantidade de vezes às expressões vinculadas à Avaliações Externas (Avaliações de desempenho, Ranqueamentos, Centralidade dos resultados em testes internacionais/nacionais, MEC/OCDE/PISA) presentes em artigos, entrevistas e reportagens selecionados na revista Veja entre 1997 até 2014 


\begin{tabular}{|c|c|c|c|c|}
\hline \multirow{2}{*}{$\begin{array}{c}\text { TEMA } \\
\text { Avaliações } \\
\text { Externas }\end{array}$} & \multicolumn{4}{|c|}{ TIPO DE PUBLICAÇÃO } \\
\hline & ARTIGOS & ENTREVISTAS & REPORTAGENS & TOTAL ANO \\
\hline 1997 & & & 1 & 1 \\
\hline 1998 & 1 & & 2 & 3 \\
\hline 1999 & & & 1 & 1 \\
\hline 2000 & 2 & & & 2 \\
\hline 2001 & 1 & & 1 & 2 \\
\hline $\begin{array}{l}2002 \\
2003\end{array}$ & $\begin{array}{l}1 \\
2\end{array}$ & & 1 & $\begin{array}{l}1 \\
3\end{array}$ \\
\hline $\begin{array}{l}2004 \\
2005\end{array}$ & $\begin{array}{l}2 \\
1\end{array}$ & & $\begin{array}{l}1 \\
1\end{array}$ & $\begin{array}{l}3 \\
2\end{array}$ \\
\hline 2006 & 3 & 1 & 1 & 5 \\
\hline 2007 & 6 & & 8 & 14 \\
\hline 2008 & 4 & 2 & 5 & 11 \\
\hline 2009 & 5 & 2 & 6 & 13 \\
\hline 2010 & 6 & 1 & 5 & 12 \\
\hline 2011 & 6 & 1 & 6 & 13 \\
\hline 2012 & 10 & 1 & 6 & 17 \\
\hline 2013 & 9 & 1 & 6 & 16 \\
\hline 2014 & 8 & 2 & 5 & 15 \\
\hline TOTAL & 67 & 11 & 56 & 134 \\
\hline
\end{tabular}

\section{C) Parcerias}

Parceria público privado (PPP) é um termo frequentemente usado que se refere a parcerias entre o poder público e o setor privado, podendo ser este com ou sem fins lucrativos. Quando uma prefeitura delega parte das vagas da educação infantil a uma creche filantrópica ou mesmo particular, por meio de um convênio entre as duas partes, configurase num exemplo desse tipo de parceria.

As parcerias com o setor privado são frequentemente elogiadas e defendidas nos conteúdos da revista Veja. No entanto, um estudo do grupo de pesquisas ao qual faço parte, 
GREPPE, investigou algumas parcerias do Instituto Ayrton Senna (IAS) com alguns municípios brasileiros e revelou alguns dados preocupantes que vão de encontro com a perspectiva de efetivação da gestão democrática na educação pública brasileira. O estudo analisou os Programas Gestão Nota 10 e Escola Campeã, ambos do IAS, em parceria realizada com 10 municípios brasileiros.

É possível perceber, através dos estudos de caso, que o IAS influenciou na gestão do sistema e da escola, modificando o desenho institucional, a legislação, a concepção de gestão, estabelecendo hierarquias e principalmente retirando a possibilidade de liberdade de ensino, já que havia controle tanto das metas, quanto das rotinas de todos: secretário de Educação, pessoal da secretaria da escola, coordenador pedagógico, diretor, aluno. Em alguns casos, a parceria acabou, mas a legislação permanece, em outros, as rotinas permanecem nas escolas ou a lógica encontra-se subjacente ao previsto no Projeto Político Pedagógico ou similar. (ADRIAO; PERONI, 2011, p. 51)

Nota-se que essa parceria hierarquizou e centralizou o comando das ações, dividindo planejamento da execução. O grupo IAS planejava e controlava as ações e a autonomia das escolas e dos profissionais da educação se restringiam à execução dos planos. A inserção do grupo incidia inclusive na participação da comunidade escolar:

No caso do IAS, os mecanismos da eleição e da participação da comunidade se articulavam a uma lógica competitiva e, ao mesmo tempo, centralizadora dos processos decisórios pelo órgão gestor da esfera governamental e, além disso, o que é mais problemático, por uma instituição privada como o IAS. Essa perspectiva centralizadora pode ser evidenciada tanto no controle privado dos dados educacionais de um setor público, quanto no estabelecimento de metas iguais para o desempenho a serem atingidas por redes tão díspares quanto São José do Rio Preto e Mossoró. (ADRIAO; PERONI, 2011, p. 51) 
Percebe-se que o grupo IAS inclusive controlava os dados educacionais produzidos com as experiências dessas parcerias, dados da de uma rede pública que iam para o controle de um órgão privado. Ademais, incluíam metas de desempenho idênticos aos municípios mais dispares. Uma efetiva mensuração gerencial que desconhece as realidades do nosso país e os abismos educacionais entre regiões.

E é por isso mesmo, que essas Parcerias viraram outra categoria relevante para esta pesquisa, parcerias sejam elas: por meio da compra de sistemas de ensino privado pelo setor público, seja pela participação dos institutos, fundações na gestão de escolas públicas. 
Tabela 3 - Referências em quantidade de vezes às expressões vinculadas à Parcerias (Apresentam conteúdo sobre sistemas apostilados, Indicam parcerias do setor público com o privado e/ou implantação de modelos de gestão do setor privado em escolas públicas, Apresenta o terceiro setor como um grande e possível parceiro capaz de transformar a educação pública do país) presentes em artigos, entrevistas e reportagens selecionados na revista Veja entre 1997 até 2014

\begin{tabular}{|c|c|c|c|c|}
\hline \multirow{2}{*}{$\begin{array}{c}\text { TEMA } \\
\text { Parcerias }\end{array}$} & \multicolumn{4}{|c|}{ TIPO DE PUBLICAÇÃO } \\
\hline & ARTIGOS & ENTREVISTAS & REPORTAGENS & $\begin{array}{c}\text { TOTAL } \\
\text { ANO }\end{array}$ \\
\hline 1997 & & & 1 & 1 \\
\hline 1998 & 1 & & 1 & 2 \\
\hline $\begin{array}{l}1999 \\
2000\end{array}$ & 2 & & & 2 \\
\hline 2001 & & & & \\
\hline 2002 & & & 1 & 1 \\
\hline $\begin{array}{l}2003 \\
2004\end{array}$ & 1 & 1 & 1 & $\begin{array}{l}2 \\
1\end{array}$ \\
\hline 2005 & 1 & & 1 & 2 \\
\hline 2006 & 3 & & 1 & 4 \\
\hline 2007 & 3 & 1 & 3 & 7 \\
\hline 2008 & 3 & & 3 & 6 \\
\hline 2009 & 4 & 1 & 2 & 7 \\
\hline 2010 & 3 & & 4 & 7 \\
\hline 2011 & 3 & 1 & 2 & 6 \\
\hline 2012 & 4 & 1 & 3 & 8 \\
\hline 2013 & 3 & & 2 & 5 \\
\hline 2014 & 2 & 1 & 3 & 6 \\
\hline TOTAL & 33 & 6 & 28 & 67 \\
\hline
\end{tabular}


Assim como nas demais tabelas, é a partir de 2006 que a incidência de conteúdos sobre este tema passa a se tornar mais recorrente no corpo da revista. Este tema abrange todas as publicações sobre gestão escolar que:

- Apresentam conteúdo sobre sistemas apostilados;

- Indicam parcerias do setor público com o privado e/ou implantação de modelos de gestão do setor privado em escolas públicas;

- Apresenta o terceiro setor (empresariado) como um grande e possível parceiro capaz de transformar a educação pública do país;

Importante ressaltar que já em 1998 Cláudio Moura Castro tecia elogios ao programa Acelera Ayrton Senna do Instituto Ayrton Senna em que os alunos eram colocados repetentes eram colocados em chamadas classes de aceleração para retomarem o tempo perdido e aprenderem o que não haviam aprendido. Segundo o articulista "O programa especial do Projeto Acelera Brasil destrói alguns mitos. Fracasso e repetência não são uma maldição dos deuses, mas uma barbeiragem crônica na gestão da escola" (Edição 1.540, 01 abril 1998, p. 103). Com essa afirmação, o autor já destaca para importância da gestão escolar e da incidência do instituto como ente privado promotor de qualidade na gestão da educação pública. No fim deste mesmo artigo Cláudio Moura Castro apresenta os benefícios do programa e conclama o poder municipal para estabelecer convênio com o Instituto.

Mesmo os alunos mais pobres dos Estados mais pobres mostram bons resultados quando tratados com métodos apropriados e quando sua autoestima é reforçada, em vez de castigada. Mesmo os mestres mais abandonados mostram resultados extraordinariamente positivos quando amparados por uma estrutura forte e corretamente orientada... A bola está com os prefeitos. Ayrton Senna está na "pole position" esperando quem acelere com ele. (CASTRO, p. 103, 1998)

Nesta última frase ao fazer analogia com a "pole position" (posição alcançada por aquele que realiza a volta mais rápida antes de um grande prêmio de Fórmula 1 e que 
Ayrton Senna tantas vezes conquistou em sua carreira), o articulista coloca o Instituto Ayrton Senna na vanguarda dos programas sobre educacionais com vistas a atingir bons resultados. Este artigo retrata que desde o final dos anos 90 já havia uma preocupação da revista em destacar parcerias do setor público com o setor privado, em que este traria soluções para administração pública cujos governos não conseguiam solucionar sozinhos.

Entretanto, este movimento dar espaço editorial as parcerias com o terceiro setor se acentua mesmo a partir do ano de 2006. Coincidentemente é o ano da fundação do Todos pela Educação. Além disso, é o primeiro ano em que Gustavo loschpe começa a escrever para revista Veja. Logo no seu primeiro artigo, Gustavo loschpe destaca a importância dos economistas e empresários para revolucionarem a educação: "Apesar da resistência que educadores e pedagogos têm à intromissão economistas, empresários e afins, em seu território, é neles que se encontrará a revolução educacional que o país necessita" (VEJA, 2006, p. 104-105).

Além dos artigos, reportagens também trazem conteúdos acerca das parcerias entre o setor público e o privado. Na reportagem de Camila Antunes na Edição 1.995, 14 fevereiro 2007, p. 94-95, intitulada como "Escola Pública, Gestão Particular", destaca-se a venda de um sistema de ensino para alguns municípios paulistas. A reportagem retrata que das dez escolas mais bem colocadas no ranking do MEC, sete delas tem parcerias com o sistema de ensino COC. Segundo a reportagem:

O que mais surpreende nessa nova modalidade de escola pública, no entanto, é a sua eficácia acadêmica. De acordo com o ranking do MEC, a união dos governos com a iniciativa privada tem produzido raras ilhas de excelência num sistema que há décadas forma estudantes de ensino básico incapazes de ler um bilhete e que desconhecem as operações básicas de matemática... o bom desempenho em sala de aula não depende de soluções pedagógicas mirabolantes, mas, sim, da implantação e execução disciplinada de um conjunto simples de medidas. É o que ocorre com as escolas públicas sob o comando do COC. A fórmula em vigor no interior de São Paulo reforça a eficácia de um tripé consagrado $\mathrm{n}$ os países onde a educação dá certo. (VEJA, 2007, p. 94-95) 
Este tripé se configura da seguinte forma:

- Exército de professores bem treinados

- Escolas permanentemente sob avaliação

- Eficiência do reforço aos estudantes com dificuldade

Importante ressaltar os termos oriundos da administração gerencial que perpassam a reportagem, tais como: eficácia, eficiência, ilhas de excelência. A lógica do setor privado é dada como fator preponderante para o sucesso de tais escolas. É desta forma que a conclusão dada pela reportagem não deixa dúvidas sobre isso: "Sete cidades de São Paulo campeãs em ensino adotam essa fórmula - prova de que o sucesso acadêmico pode resultar de um conjunto simples de medidas". (VEJA, 2007, p. 94-95)

Embora à primeira vista o sistema apostilado pareça ser a salvação do ensino público, em nenhum momento a reportagem faz menção ao momento em que se instaurou a parceria, se antes dos testes que produziram tal colocação no ranking das escolas mais bem avaliadas pelo MEC, ou depois. Além disso, não analisam também quais eram as notas e as posições antes da parceria com o sistema de ensino COC. Nesse sentido, não há uma perspectiva histórica de evolução das notas, um antes e depois da entrada do COC nesses municípios. Mesmo que não houvesse criticas a tecer sobre a lógica da administração, gestão privada na educação pública, a conclusão citada no corpo da publicação não se sustenta.

Em outro artigo de Cláudio Moura Castro, o autor defende as alianças entre setor privado e o público. Analisando o Sistema de Gestão proposto pela Fundação Pitágoras (SGI), o articulista com base apenas nos resultados das avaliações externas compara três municípios que utilizam o referido sistema de gestão com outros quinze que não utilizam. Segundo o autor: 
Vejamos o exemplo do Pitágoras [onde o autor trabalha], cuja fundação criou o Sistema de Gerenciamento Integrado (SGI), que também recebe apoio de grandes empresas. Tomemos os três municípios mineiros com SGI, que estão na região de Sete Lagoas (Jequitibá, Funilândia e Baldim). Nas provas oficiais de avaliação do ciclo inicial, obtiveram $46 \%$ de alunos alfabetizados. No total dos quinze municípios sem SGI, a média foi de $22 \%$. Ou seja, a porcentagem de alfabetizados dos três é mais que o dobro da dos outros. Nem nos municípios mais ricos da região os resultados se aproximam dos que têm o SGI" (CASTRO, 2007, p. 22).

\section{D) Diretor Escolar}

A última categoria que é base de análise teórica é o Diretor Escolar. A comparação do diretor com a de um gerente dentro de uma empresa é recorrente e aparecem tanto nas entrevistas, reportagens e artigos. Segue a tabela de aparições deste conteúdo ao longo das publicações sobre gestão escolar. 
Tabela 4 - Referências em quantidade de vezes às expressões vinculadas à Diretor Escolar presentes em artigos, entrevistas e reportagens selecionados na revista Veja entre 1997 até 2014

\begin{tabular}{|c|c|c|c|c|}
\hline TEMA & \multicolumn{3}{|c|}{ TIPO DE PUBLICAÇÃO } & \\
\hline Diretor Escolar & ARTIGOS & ENTREVISTAS & REPORTAGENS & TOTAL ANO \\
\hline $\begin{array}{l}1997 \\
1998 \\
1999\end{array}$ & & & & \\
\hline 2000 & & & & \\
\hline 2001 & & & & \\
\hline 2002 & 1 & & & 1 \\
\hline $\begin{array}{l}2003 \\
2004\end{array}$ & 1 & & & 1 \\
\hline 2005 & & & & \\
\hline 2006 & 1 & & 1 & 2 \\
\hline 2007 & 1 & 1 & & 2 \\
\hline 2008 & 1 & 1 & 1 & 3 \\
\hline 2009 & 2 & 2 & & 4 \\
\hline $\begin{array}{l}2010 \\
2011\end{array}$ & $\begin{array}{l}2 \\
1\end{array}$ & $\begin{array}{l}1 \\
1\end{array}$ & $\begin{array}{l}1 \\
1\end{array}$ & $\begin{array}{l}4 \\
3\end{array}$ \\
\hline 2012 & 2 & 1 & 1 & 4 \\
\hline 2013 & 3 & 1 & & 4 \\
\hline 2014 & 2 & & 1 & 3 \\
\hline TOTAL & 17 & 8 & 6 & 31 \\
\hline
\end{tabular}

Destacam-se nos dados que até o ano de 2006 o tema diretor escolar é abordado em apenas duas publicações (a primeira em 2002 e a outra em 2004). É a partir do ano de 2006 que conteúdos sobre o diretor começam a aparecer com frequência. De 2006 até 2014, esta temática apresenta variação de inserções na revista entre duas a quatro por ano de edições. Só no ano de 2009, houve o dobro de publicações sobre este tema em comparação com todo o período de 1997-2005. Mais uma vez os dados apresentam uma 
mudança editorial na quantidade de publicações sobre a temática gestão escolar a partir do ano de 2006. O tema especifico diretor escolar segue o mesmo movimento editorial. Necessário destacar que os articulistas que abordam esta discussão temática em suas publicações são os mesmos que apresentam maior número de artigos publicados sobre educação e gestão escolar: Cláudio Moura Castro e Gustavo loschpe.

Pelo levantamento dos dados, nota-se que dentre as publicações que versam sobre o diretor escolar, a forma como estes profissionais são escolhidos para atuarem em suas escolas é uma característica importante de destacar: devem ser escolhidos por meio de um processo seletivo e eleição da comunidade escolar. Destaca-se que esse processo seletivo em alguns momentos pode aparecer como concurso, em outros como prova ou algum instrumento que mensure capacidade técnica que atenda às exigências das secretarias, seja estadual ou municipal. Especialmente Cláudio Moura Castro e Gustavo loschpe defendem esta perspectiva de processo seletivo e eleição. As escolhas por indicação política são criticadas por estes articulistas. Cláudio Moura Castro em um artigo publicado em 2008 afirma:

Como a escola tem a cara do diretor, a sua escolha irresponsável arruína o ensino. Onde isso ocorre, os professores se sentem desvalorizados e manipulados pela burocracia. Os mais graves pepinos estão no clientelismo do governo local. A politicagem passa na frente das preocupações com a qualidade. (CASTRO, 2008, p. 16)

Ainda em outro artigo do mesmo autor, em que este ressalta algumas características que funcionam para se ter uma escola de qualidade, a escolha do diretor aparece como um fator que influencia na obtenção de bons resultados para escola. No artigo, o autor elogia os Estados do Acre e Sergipe por terem aderido à escolha dos diretores, por meio de concurso e eleição, como uma das medidas que dão certo para elevar a qualidade da escola. Ademais, compara estas iniciativas com as realizadas em Minas Gerais ainda nos anos 90 . $O$ autor aponta neste artigo: 
Tais avanços confirmam os registrados em Minas Gerais, na década de 90, onde se originaram algumas ideias adotadas por Acre e Sergipe...

Redução severa da burocracia central e um sistema pioneiro de avaliação de todas as escolas. Os diretores passaram a ser escolhidos por concurso e eleição dentre os mais bem colocados. A fórmula mostrou resultados excepcionais. (CASTRO, 2006, p. 20)

Além de Castro, Gustavo loschpe também destaca a importância de se realizar a escolha dos diretores por meio de processo de seleção e posterior eleição da comunidade escolar. Em um artigo de 2012, no qual loschpe analisa as propostas para educação de candidatos para diversas prefeituras, o autor destaca:

É curioso que os candidatos não falem quase nada a respeito de um profissional que tem importância decisiva na qualidade de uma instituição de ensino e sobre o qual os prefeitos, sim, têm influencia: o diretor de escola. Duas medidas simples já ajudariam: aumentar o salário dos diretores... e prometer que não haverá indicação política para esse cargo, e sim processo seletivo composto de prova e posterior eleição pela comunidade escolar. (IOSCHPE, 2012, p. 112)

Importante ressaltar que para loschpe o aumento do salário do diretor é um indicador que influencia no bom rendimento dos alunos na escola, ao passo que o aumento para os professores, segundo ele, não auxilia em nada. Por isso defende, para os professores, a política de premiação ao mérito por desempenho em avaliações externas. Outra característica importante que os conteúdos sobre o diretor escolar revelam é para que este profissional tenha maior autonomia para conduzir a parte administrativa e financeira da escola. Em uma das entrevistas nas páginas amarelas Eric Nadelstern, então CEO na secretaria de educação da cidade de Nova York e responsável por uma reforma nas escolas daquela localidade, afirma: 
No novo sistema, os diretores recebem dinheiro da prefeitura e são livres para administrar a escola como julgarem melhor. Como esperar que os diretores sejam gestores tão eficazes quanto os das grandes empresas se os privamos de poder? É ilógico. (VEJA, 2007, p. 14)

Observa-se que o diretor é comparado com a de um gestor de uma grande empresa. Além disso, a autonomia referida como, liberdade para administrar a escola como julgar melhor, está imbricada a outra dimensão da administração: o poder. Nessa perspectiva, mais liberdade para o diretor significa também mais poder para esse sujeito. Este posicionamento se coaduna com o de Cláudio Moura Castro. O autor afirma, entre outros fatores, que uma boa escola e bons sistemas educacionais ocorrem quando:

As autoridades dão às escolas muita autonomia para operar. Há forte liderança do diretor ("a escola tem a cara do diretor"). Ele manda. É um real gerente, estando livre para se mover. Mas deve atingir as metas estabelecidas, e seu desempenho é avaliado com rigor. (CASTRO, 2007, p. 24)

Nota-se que a expressão muita autonomia para operar as escolas não está ligada aos vários sujeitos que compõem a comunidade escolar, mas sim a figura do diretor que deve promover forte liderança e mandar tal qual um gerente. Outro aspecto importante de observar é que o diretor é colocado numa posição de liberdade para se mover (no sentido de administrar a escola), porém num momento seguinte, a tal liberdade é restringida a um universo de metas a cumprir. Metas que precisam ser executadas e serão avaliadas com rigor pelos setores que supervisionam o trabalho do diretor. Novamente, Eric Nadelstern, responsável pela reforma nas escolas de Nova York, ressalta sobre o diretor: 
Damos autonomia e, em troca, o diretor assina um contrato com a prefeitura em que se compromete a fazer seus estudantes alcançarem uma determinada média de notas, a reduzir a evasão, a combater a repetência, e por aí vai. Se as escolas não cumprem tais metas, recebem menos dinheiro do que as demais que mostram avanço nos indicadores. Nas escolas em que o resultado é péssimo, não há saída senão demitir os diretores. No mundo privado, não causa espanto que alguém de alto escalão seja mandado embora por incapacidade de gestão. Na escola pública, isso ainda é visto como uma injustiça. Para mim, é mais um sinal de que as escolas têm muito a aprender com as empresas. (VEJA, 2007, p. 14)

Sob esta ótica apresentada, a autonomia fica condicionada a uma série de metas e resultados que precisam ser alcançados. Se a escola não alcança as metas o diretor pode ser demitido. Esta autonomia também responsabiliza a escola pelo seu fracasso ou sucesso e especialmente é o diretor quem terá o maior peso de responsabilidade nas costas. Exemplo desta perspectiva sobre a responsabilização do diretor no Brasil advém da reportagem de Camila Pereira, publicada em 2008. Segundo a reportagem que, relata uma parceria entre o setor público e privado na gestão de Pernambuco, os "Diretores à frente de uma escola cujos alunos não avançam nas médias, por sua vez, são removidos do cargo". (VEJA, 2008, p.78)

Em outras publicações o diretor também é associado a um gerente, líder que, como Cláudio Moura Castro afirma, deve "criar um ambiente positivo e estimulante para os seus professores" e promover escolas "bem lideradas". (CASTRO, 2008, p. 16). Ainda sobre a liderança do diretor, Maria Helena Guimarães de Castro (então secretária de educação do Estado de São Paulo), entrevistada nas páginas amarelas em 2008, afirma: 
Há um fator comum a todas as escolas nota 10, e ele merece a atenção das demais: trata-se da presença de um diretor competente, com atributos de liderança semelhantes aos de qualquer chefe numa grande empresa. Sob sua batuta, os professores trabalham estimulados, os alunos desfrutam um clima positivo para o aprendizado e os pais são atraídos para o ambiente escolar. Se tais diretores fossem a maioria, o ensino público não estaria tão mal das pernas. (VEJA, 2008, p. 9-13)

A então secretária de educação aponta para o importante papel de liderança que o diretor deve assumir. Não obstante, dialoga com Moura Castro ao afirmar que sob uma boa liderança (como qualquer chefe de uma grande empresa) os professores trabalham estimulados. Nesse sentido, constrói uma ideia de que o professor precisa ser bem liderado e estimulado para realizar um bom trabalho, do contrário ele fracassará. Nessa perspectiva, a autonomia do professor fica muito comprometida, enquanto a responsabilidade do diretor se eleva sobremaneira.

Ainda sobre o papel do diretor e a importância de sua liderança, Paulo Renato Souza (então como secretário da Educação do Estado de São Paulo), quando entrevistado nas páginas amarelas em 2009, aponta:

As boas escolas são comandadas por diretores com uma visão moderna de gestão, coisa raríssima no país. Não existe no Brasil nada como um bom curso voltado para treinar esses profissionais a liderar equipes ou cobrar resultados, o básico para qualquer um que se pretenda gestor. Quem se sai bem na função de diretor, em geral, é porque tem algo como um dom inato para a chefia. (VEJA, 2009, p.19-23)

Novamente o diretor é apontado como um sujeito que precisa saber liderar equipes e cobrar resultados, além de obter uma visão moderna de gestão para o exercício da chefia da escola. Esses princípios defendidos por essas pessoas citadas se encontram dentro de um escopo que tenta transferir a lógica gerencial para dentro das escolas. Vitor Paro apresenta importante reflexão de como a gerência, enquanto mecanismo de controle e 
coordenação dos esforços coletivos sob o sistema capitalista se manifesta na escola, sobremaneira sob o controle das atividades e funções do diretor escolar.

A gerência, como controle do trabalho alheio, forma que assume a coordenação do esforço humano coletivo sob o capitalismo, faz-se presente na realidade concreta da unidade escolar, perpassando todo o conjunto das atividades que aí se realizam. Esse processo se dá, entretanto, sem os requintados procedimentos de liderança e relações humanas, desenvolvidos na teoria e na prática de administração de empresas. A preocupação com esses procedimentos parece restringir-se muito mais, por enquanto, aos manuais de Administração Escolar, especialmente aos de procedência norte-americana. Nem por isso, todavia, deixa de predominar, na escola, um sistema hierárquico análogo ao da empresa capitalista. Assim, a última palavra deve ser dada por um diretor, colocado no topo dessa hierarquia, visto como o representante da lei e da ordem e responsável pela supervisão e controle das atividades que aí se desenvolvem. Para facilitar essa supervisão, tal sistema hierárquico é constituído de tal maneira que todos os que participam da vida da instituição - desde o pessoal de secretaria e os funcionários subalternos (serventes, inspetores de alunos, etc.), passando pelo pessoal técnico-pedagógico (orientador educacional, coordenador pedagógico, etc.), até os professores e alunos - devem desempenhar funções precisas o suficiente para permitir o controle e a cobrança no cumprimento das tarefas e atribuições que estão sob a responsabilidade e obrigação de cada um. (PARO, 2012, p. 173)

Outro aspecto relevante para reflexão repousa em como os conteúdos levantados aparentam apresentar uma perspectiva democrática quando se trata das escolhas dos diretores. Um desenho que destaca a realização de provas e posterior eleição da comunidade escolar. No entanto, esse suposto movimento democrático, obedece a uma lógica de ordem econômica que se distancia de uma perspectiva de gestão verdadeiramente democrática. Como nos aponta SOUZA (2001), há orientação de organismos multilaterais como Banco Mundial, que em 1995, destaca exatamente a 
importância de que diretores escolares sejam escolhidos pela comunidade escolar e não nomeados por indicação do executivo ou apadrinhamento político. A defesa desse pensamento consiste na possibilidade de se obter mais proximidade com a comunidade escolar, que pode auxiliar a escola, inclusive com ajuda de ordem econômica. Além disso, essa eleição, segundo as prescrições de tais organizações multilaterais para educação, acarretaria na satisfação das famílias por participarem da escolha do diretor, e uma vez satisfeitas, na disposição a contribuir mais com a escola do ponto do ponto de vista econômico. Assim, certa perspectiva de democracia estaria sendo gestada com o intuito apenas de aproximar a comunidade da escola e legitimar o poder exercido pelo diretor dentro do âmbito escolar.

No entanto, a lógica que incide sobre a organização do trabalho dentro da escola se apresenta altamente hierarquizada. Sob um viés da administração gerencial proveniente do setor privado, o diretor ganha ainda mais importância na administração e condução das metas e resultados propostos pelos setores que comandam e supervisionam as escolas (secretarias de educação, por exemplo). Expressões como liderança, promover um ambiente mais positivo, estimular os professores, ser o gerente da escola são conhecidas na gestão das empresas privadas e trazidas para o ambiente escolar, especialmente sob a figura do diretor como aquele que colocará em prática tais princípios.

Assim cabe aqui uma reflexão de Vitor Paro quando destaca a dicotomia em que se encontra o diretor escolar quando está sob o comando de mecanismos gerenciais da administração capitalista e precisa atingir os fins pedagógicos da escola. 
Onde a adoção dos mecanismos gerenciais da administração capitalista na escola repercute de forma especialmente singular é precisamente no papel desempenhado pelo diretor escolar, que passa a assumir, nesse processo, posição bastante contraditória, já que tem de exercer duas ordens de funções, em princípio, inconciliáveis: como educador, ele precisa cuidar da busca dos objetivos educacionais da escola; como gerente e responsável último pela instituição escolar, tem de fazer cumprir as determinações emanadas dos orgãos superiores do sistema de ensino que, em grande parte, acabam por concorrer para a frustração de tais objetivos. (PARO, 2012, p. 174)

Nesta perspectiva, um diretor eleito pela comunidade escolar, conseguirá promover a participação dos mais diversos sujeitos da comunidade escolar? Será possível conduzir uma gestão democrática que leve em conta os interesses de toda a comunidade escolar? É importante lembrar que as metas do diretor nesta perspectiva, na maioria das vezes, estão associadas a resultados em avaliações externas. Neste sentido, a autonomia cada vez maior para o diretor contempla a dimensão pedagógica? Ou apenas financeira? 


\section{4 - O CONTEÚDO SOBRE GESTÃO ESCOLAR DENTRO DA REVISTA VEJA - UMA ANÁLISE SOBRE A CONCEPÇÃO DE GESTÃO PRESENTE}

Neste capítulo pretendo incursionar sobre a concepção de gestão escolar presente na Revista Veja. Tratarei do gerencialismo e a lógica empresarial como mecanismo de administração defendida pela revista como fatores que promoverão a boa qualidade do ensino e a boa gestão das escolas públicas. Os dados apontam que a Revista Veja, por meio de seus conteúdos, apresenta a defesa de incorporar a lógica de competitividade, meritocracia e aferição em testes padronizados, que está presente nas empresas e na sociedade em geral, para dentro das escolas públicas. Essa lógica aparece no corpo dos textos seja pela defesa de determinações e elaboração de diretrizes pelo corpo técnico das secretarias de educação para serem seguidos nas escolas. Seja por parcerias com o setor privado, desde aquelas que consomem produtos educacionais, até aquelas que prestam consultoria e assessoria técnica, muitas vezes por meio de fundações, ONGs, etc.

Antes, porém, destaco que as escolhas editoriais da Revista Veja apresentam uma organicidade intencional e estratégica para tratar dos assuntos relativos à educação. Não é em todas as edições que há conteúdos sobre educação. Por vezes, a revista fica três, quatro até mais edições sem veicular nada sobre o tema educação. Revelador é que em muitos momentos, temos numa mesma edição duas ou até mais inserções sobre o tema educação. E, embora não se tenha um padrão de repetição desses acontecimentos, é também verdade, que eles acontecem com alguma freqüência. Por exemplo, em 2008 tivemos 32 edições que apresentaram conteúdos sobre educação. Em 12 edições, apareceram duas ou mais inserções de conteúdos sobre o tema em questão. Na edição de número 2.047 tivemos artigos de Gustavo loschpe e Claudio Moura Castro, além de uma entrevista nas páginas amarelas. Ademais, todos estes conteúdos apresentavam questões referentes ao campo da gestão escolar. Em 2009, na edição 2.100, tivemos 4 inserções sobre educação, sendo 3 (artigos de loschpe e Moura Castro e uma reportagem) delas contemplando a temática gestão escolar. É possível afirmar que após 2006, em ao menos um terço das edições com conteúdos educacionais, há mais de uma inserção tratando sobre questões educacionais. 
Esta característica apresenta uma estratégia em discutir educação de uma forma mais concisa e incisiva. Permanecer várias edições sem apresentar nada sobre educação e depois numa mesma edição ter quatro inserções pode representar uma perspectiva de organizar os conteúdos de cada edição estrategicamente. Na edição 2.283 temos três inserções, todas elas tratando sobre gestão escolar: uma reportagem que compara locais pobres com escolas precárias e IDEB alto com outras escolas situadas em bairros de classe média e IDEB baixo; um artigo do Cláudio Moura Castro em que defende uma reforma educacional na perspectiva de uma reforma para um ensino mais técnico e voltado para o mercado de trabalho; e, nessa mesma linha de raciocínio, temos uma entrevista com João Batista Araujo e Oliveira, apresentado na entrevista pela repórter como um dos criadores do prêmio prefeito nota 10. Esse prêmio, segundo a entrevista, iria dar $\mathrm{R} \$ 200.000$ mil reais a administradores municipais cujas redes de ensino obtivessem melhor avaliações na Prova Brasil. Desta entrevista destaco duas falas:

No Brasil, o que importa é o acessório, ensinar xadrez ou teatro. Isso acontece porque as escolas e as secretarias de Educação estão povoadas de pedagogos, e não de gestores... Insistimos em fazer um ensino acadêmico, que reprova alunos e nega um futuro a essas pessoas. $O$ currículo tem de ser voltado para a massa que vai enfrentar o mercado de trabalho. Uma formação técnica. (VEJA, 2012, p. 21)

Essa perspectiva apresentada é consonante com a qual Cláudio Moura Castro nesta mesma edição compactua. Façamos um exercício: seja um leitor esporádico ou um assinante mensal, quando tiver acesso a esta edição se deparará com três conteúdos que tratam de temas relativos a gestão escolar. Verá que eles parecem conversar e estão muito ligados. Uma reportagem compara resultados de avaliações externas, um entrevistado organiza premiações a gestores municipais que tem seus sistemas educacionais bem avaliados segundo um teste padronizado larga escala (IDEB). O mesmo entrevistado defende uma formação nas escolas públicas mais técnica voltada para o mercado de trabalho. Mesma aspiração do articulista que escreve com freqüência na revista. 
Há uma correlação editorial e estratégica que apresenta pontos de vista muito semelhantes sobre educação e gestão escolar. O leitor poderá ter a tendência a levar em conta a opinião apresentada nesta edição. Afinal são apresentados (articulista e entrevistado) como especialistas em educação. E poderá achar que pedagogos, por exemplo, cuja formação é voltada exclusivamente aos saberes educacionais construídos historicamente, não tem competência para atuar na gestão de uma escola. Certamente, se for levar em consideração a opinião daqueles que a revista Veja aponta como especialistas em educação construirá no senso comum uma idéia de que a escola deve formar apenas para o mercado de trabalho, que pedagogos e professores não entendem nada de educação, mas aqueles que realmente conhecem profundamente a educação são formados em economia, administração, etc.

Para contrapor essa idéia dominante na revista, Luiz Carlos de Freitas (2011) discute a consolidação do neotecnicismo no Brasil e desvela qual a concepção que pessoas, que ele chama de reformadores empresariais, têm sobre educação. 
Os reformadores empresariais entendem que a escola é boa quando os alunos têm notas altas em Português e Matemática - no máximo incluindo Ciências. Essa concepção de educação centra a ação da escola no desenvolvimento de um aspecto do ser humano: a habilidade cognitiva. $\mathrm{Na}$ esteira dessa decisão, associam - como critica Diane Ravitch - notas altas nessas disciplinas com boa educação. Boa parte dos países desenvolvidos está nessa corrida para verificar quem é melhor em língua materna, Matemática e Ciências, comandada pela OCDE, e impõe esse critério aos menos desenvolvidos. Tais habilidades cognitivas não são desprezíveis, mas são amplamente insuficientes. Primeiro porque, mesmo no plano cognitivo, não existem somente essas disciplinas na escola. Segundo porque o ser humano tem outras esferas de desenvolvimento igualmente importantes. Consideraríamos uma escola que desenvolve a criatividade, desenvolve a capacidade emocional e afetiva das crianças, cuida muito bem do desenvolvimento do corpo, desenvolve sua capacidade artística, mas não é tão boa em Português e Matemática uma má escola? A TRI (Teoria da Resposta ao Item) poderia ser usada para examinar essas áreas também. Não é falta de tecnologia de medição. Mas o custo talvez seja impeditivo, argumentarão. Bem, então significa que medimos o que o dinheiro dá para medir? Muito provavelmente os reformadores empresariais responderiam positivamente a essas questões, já que, para eles, passar em um teste de Português e Matemática é sinônimo de ter boa educação. Entretanto, o ser humano pode desenvolver-se em múltiplas direções, como apontamos antes, e a escola deve prover condições para que ele possa explorar e desenvolver todas essas dimensões, e não apenas uma delas a cognitiva. (FREITAS, 2011, p. 78)

Diversas dimensões do aprendizado são ignoradas se pensamos numa formação tecnicista voltada apenas ao mercado de trabalho. Além disso, sabemos que a Prova Brasil só avalia as linguagens de Português de Matemática, desconsiderando outros aspectos cognitivos fundamentais, como as ciências da natureza, história, geografia, arte. Ou seja, mesmo quando se trata da cognição, é apreciado apenas um pequeno grupo de saberes, 
enquanto outros são ignorados. Porém, como Freitas coloca, nós seres humanos não vivemos apenas da cognição, e o cognitivo não está dissociado dos aspectos corporais e emotivos. A educação precisa ser completa, contemplar todas as esferas que apresenta um ser humano. Por isso mesmo, Freitas, apresenta uma reflexão importante sobre a educação:

A educação é sempre um campo em disputa. Tem uma ligação tão grande com as questões relativas à formação de mão de obra em nossa sociedade que economistas, muitas vezes escalados pelos interesses dos empresários, predominam na hora de definir os caminhos da educação. Educadores profissionais pouco são ouvidos na elaboração das políticas públicas educacionais, e a mídia, em particular, abre mais espaço para os homens de negócio e seus representantes - e muito menos para educadores. A conversa é sempre a mesma. Os educadores não são objetivos ou não têm propostas concretas. São ideólogos, e não cientistas. Os reformadores empresariais procuram se contrapor dizendo que eles, sim, são objetivos e não fazem ideologia. Como se isso fosse possível, pois não fazer ideologia já é uma opção ideológica. (FREITAS, 2011, p.79)

Percebe-se claramente que o autor demonstra uma posição muito distinta daquela que a revista Veja costuma publicar em seus conteúdos sobre educação. Nesse sentido, é fundamental levantar a questão: Será a Revista Veja um espaço aberto ao contraditório e amplo debate? O fato de não terem sido encontradas, ao longo desta pesquisa, publicações e/ou pessoas que apresentam um ponto de vista completamente antagônico a estes apresentados nesta edição, por exemplo, configura-se em uma ignorância acadêmica por parte de quem edita a revista ou é um fato estratégico e intencional?

\section{1 - Administração Gerencial e a lógica empresarial para dentro da escola}

Este movimento é importante para contextualizar a posição que a revista Veja defende sobre a gestão da escola pública. Tanto em reportagens, artigos e entrevistas nas páginas amarelas, alguns conceitos são defendidos como exemplos de boa qualidade na escola pública. Avaliações Externas, meritocracia, eficiência, eficácia, competitividade, ou 
seja, valores gerenciais que são tidos como exemplos de excelência nas empresas privadas são vistos como essenciais para o bom funcionamento da escola pública. Destaco personagens de cinco entrevistas em páginas amarelas:

- Eric Nadelstern na edição 2035 de 21 de novembro de 2007 p. 11-15. Em 2007, era o CEO na Secretaria de Educação de Nova York e responsável por uma reforma na rede de lá. O título da entrevista destaca: "Ensinar a competir". Ainda na apresentação do entrevistado a repórter Monica Weinberg afirma: "Nadelstern tem a função de implantar nas escolas um novo modelo cujos pilares são a competição e a recompensa baseada no mérito, tal qual no melhor setor privado". Em seguida, quando perguntado se é mesmo possível transformar as escolas de má qualidade em bons colégios, Nadelstern responde: "O primeiro passo é mudar radicalmente a velha cultura que abomina a competição e a meritocracia no ambiente escolar". Ainda sobre a defesa da meritocracia, o entrevistado ressalta: "Para fazer de uma escola um exemplo de excelência, é preciso dar incentivos concretos a quem trabalha nela, tal qual em qualquer empresa.".

- Maria Helena Guimarães de Castro na edição 2047 de 13 de fevereiro de 2008 p. 9-13. Neste momento era a secretária de educação do Estado de São Paulo sob o governo de José Serra. O título da entrevista destaca: "Premiar o mérito". A entrevistada defende a política de bônus e responsabilização das escolas. Segundo ela, "A velha política de isonomia salarial contribui para a acomodação dos professores numa zona de mediocridade." Além disso, faz uma séria critica as faculdades de educação do país. Para ela, "As faculdades de educação estão preocupadas demais com um discurso ideológico sobre as funções transformadoras do ensino. Elas acabam deixando em segundo plano evidências cientificas sobre as práticas pedagógicas que de fato funcionam no Brasil e no mundo." Em seguida, afirma: "Num mundo ideal, eu fecharia todas as faculdades de pedagogia do país, até mesmo as mais conceituadas, como a USP e a da Unicamp".

- Eric Hanushek edição 2078 de 17 de setembro de 2008 p. 19-23. Ele é um economista que realizou estudo nos EUA sobre efeitos de um bom ensino no 
crescimento econômico. O título desta entrevista foi: "Educação é dinheiro". Destaco a seguinte frase do economista quando perguntado sobre o que ele proporia para melhorar a qualidade nas escolas: "Faria muito bem as escolas manter salários mensais diferenciados para os bons professores, poder demitir os incapazes e proporcionar, enfim, um ambiente tão competitivo quanto o de uma grande empresa".

- Adreas Schleicher edição 2072 de 6 de agosto de 2008 p. 17-21. Físico alemão que na época comandava os rankings de educação da OCDE. O título da entrevista traz: "Medir para avançar rápido". Em dado momento da entrevista, contextualizando a má gestão dos recursos aplicados na educação, o físico afirma: "A educação é um setor com índices de produtividade declinantes no mundo todo: os custos só aumentam... Justamente o inverso ocorre com as grandes empresas privadas, que conseguem cortar gastos e produzir mais e melhor".

- Paulo Renato Souza edição 2136 de 28 de outubro de 2009 p. 19-23. Na época exercia o cargo de secretário de educação do governo José Serra, então governador do Estado de São Paulo. Na entrevista, destaca-se a defesa feita pelo secretário da meritocracia. Segundo ele, "É preciso premiar o esforço e talento para tornar a carreira de professor atraente... Já é consenso entre especialistas do mundo todo que aumentos concedidos a uma categoria inteira não tem impacto relevante no ensino. O que faz diferença, isso sim, é conseguir premiar os que se saem melhor em sala de aula". Além disso, como a secretária anterior também entrevistada nas páginas amarelas (Maria Helena Guimarães de Castro), Paulo Renato faz criticas as faculdades de pedagogia. "No lugar de ensinarem didática, as faculdades de pedagogia optam por perder tempo com discussões teóricas que, não raro, se baseiam em conceitos sem nenhuma comprovação cientifica".

Além das entrevistas, destaco reportagens que coadunam com a lógica empresarial na educação pública. Na edição 1995 de 14 de fevereiro de 2007 p. 94-95, o título da reportagem traz: "Escola pública, Gestão particular". A reportagem destaca a parceria de um grupo privado com diversos municípios brasileiros. A parceria em questão se deu pela 
venda do sistema apostilado do grupo COC para estes municípios. A repórter dá ênfase especialmente a sete destes municípios que se utilizam do sistema COC e estão bem rankeados entre os dez melhores no Estado de São Paulo segundo dados do MEC. Na análise, a repórter Camila Antunes não contextualiza o ranking e nem descreve se os municípios já obtinham bom desempenho antes da parceria. No entanto, ela afirma que o sucesso destas escolas se deve a parceria com este grupo privado. A reportagem destaca que "o que mais surpreende nessa nova modalidade de escola pública é a sua eficácia acadêmica". Para a repórter Camila Antunes, "o bom desempenho em sala de aula não depende de soluções pedagógicas mirabolantes, mas, sim, da implantação e execução de um conjunto simples de medidas". Além disso, ela destaca essas medidas no quadro abaixo extraído da reportagem.

Como se vê a reportagem associa a parceria como fonte motriz exclusiva dos bons resultados das escolas. Um modelo campeão como o próprio quadro traz.

Cláudio Moura Castro também ressalta a eficácia do sistema apostilado e tece elogios ao mesmo. Em artigo publicado no mesmo ano da reportagem mencionada acima o autor destaca a importância deste tipo de parceria para o setor público:

Segundo o índice de qualidade da educação do MEC (o Ideb), dentre os dez municípios paulistas com notas mais altas, seis eram apoiados por alguma rede de ensino. Ou seja, os municípios que entraram nas redes aumentaram drasticamente sua chance de estar dentre os melhores. Portanto, há claros indícios de que os apostiladores criaram uma solução brasileira de grandes méritos e originalidade. (CASTRO, 2007, p. 20)

É importante ressaltar que Cláudio Moura Castro ainda trata em outros artigos sobre os sistemas apostilados, como também sobre parcerias com o setor privado. Entre as parcerias, se destacam as do setor público com Instituto Ayrton Senna, as do SGI (Sistema de Gestão Integrado) do sistema Pitágoras. Para análise qualitativa pretendo utilizar trabalhos publicados por integrantes do GREPPE. Destaca-se: Gestão Municipal da Educação e as parcerias com o Instituto Ayrton Senna de 2013 e Políticas e Gestão da Educação: desafios em tempos de mudança de 2013. 
Em outra reportagem da edição 2006 de 2 de maio de 2007 p. 94-95, acerca da implementação de um novo pacote do governo Lula para a educação que "promete resolver o atraso brasileiro", o título destaca: "Medir, Avaliar e Premiar". A reportagem de Monica Weinberg e Marcos Todeschini ressalta sete medidas para melhorar a educação. Dentre elas destaca-se: "Avaliação e Premiação ao mérito". Mais uma vez, a avaliação e a meritocracia aparecem como conceitos que podem resolver os problemas educacionais. Ainda nesta mesma edição da revista, duas reportagens destacam municípios pequenos e pobres que estão bem ranqueados no Ideb. Os municípios, situados no interior de São Paulo e Distrito Federal, são muito pobres e suas escolas apresentam infraestrutura precária. Contudo, a argumentação defendida em ambas as reportagens é de que mesmo em condições tão desfavoráveis pode-se ter uma escola de qualidade (qualidade esta mensurada apenas pelo resultado do IDEB). $O$ título de uma destas reportagens expressa bem isso: "Luxo zero, Ensino nota dez". Nesta mesma reportagem, Cláudio Moura Castro aparece emitindo sua opinião como um especialista em educação e afirma: "O salário dos professores, assim como a infraestrutura da escola, não é determinante do bom ensino".

Destaca-se o apreço que Cláudio Moura Castro tem por Taylor, dedicando dois artigos levantados especialmente para defender as ideias do empresário. Em um dos artigos o autor destaca: "As práticas de Taylor se tornaram o cotidiano de quem opera em empresas de primeira linha". (edição n. 1969 de 16 de agosto de 2006 p. 20). Neste artigo, Cláudio Moura Castro diz que há um preconceito sobre Taylor por parte das escolas de administração e destaca que seus princípios estão na base da produção das empresas. Segundo ele não há distinções essenciais nas diversas maneiras de organizar o trabalho: "Os estilos japoneses de participação são apenas formas mais suaves de motivar e organizar o trabalho". (edição n. 1969 de 16 de agosto de 2006 p. 20). Ainda em outro artigo, já no ano de 2012, o autor seguindo a mesma lógica de enaltecer as contribuições de Taylor para a organização do trabalho, ressalta: "Sugiro aos nossos doutos professores que, antes de criticarem o taylorismo, esperem que ele chegue ao Brasil. Onde ele faz falta". (edição 2275 de 27 de junho de 2012, p. 26) 
Além de Cláudio Moura Castro, outro articulista muito presente é Gustavo loschpe. Suas principais ideias defendidas são:

1. Professores não ganham mal e precisam receber conforme sua produtividade nas avaliações externas (meritocracia, premiação).

2. O país já investe muito em educação e na realidade precisa melhorar é a sua gestão.

3. O salário do diretor sim tem influência na qualidade do ensino

4. Os conteúdos precisam ser neutros e objetivos. Segundo ele, há muita ideologia disseminada na escola pública esta precisa escolher entre formar o cidadão ou o individuo para o mercado de trabalho. Segundo ele, as duas coisas não dá.

No seu primeiro artigo escrito para a revista Veja, Gustavo loschpe destaca a importância dos economistas e empresários para revolucionarem a educação: "Apesar da resistência que educadores e pedagogos têm à intromissão economistas, empresários e afins, em seu território, é neles que se encontrará a revolução educacional que o país necessita". (edição 1971 de 30 de agosto de 2006, p. 104-105)

Neste sentido, a revista Veja faz uma clara defesa da utilização da administração privada na escola pública. No artigo publicado na edição n. 1994 de 7 de fevereiro de 2007 p. 22, Cláudio Moura Castro argumenta:

Área que chama atenção pelo contraste entre público e privado é a gestão. De um lado, parte do empresariado brasileiro avançou muito na qualidade de sua gestão. De outro, a maioria das redes municipais dá o exemplo mais rematado de primitivismo administrativo. Daí a importância de trazer a elas as boas práticas de gestão empresarial, passo inicial para que se obtenham bons resultados na educação. (VEJA, 2007, p. 22)

Neste artigo o autor elogia a aliança entre os programas de fundações privadas e o setor público. O economista cita o SGI (Sistema de Gerenciamento Integrado do grupo 
Pitágoras) e a parceria com três municípios mineiros como fator determinante para obter resultados em avaliações externas acima da média dos outros municípios de Minas Gerais. Esta analogia feita pelo autor não considera resultados antes da parceria. Apenas aponta o resultado mais recente e conclui: "Nem nos municípios mais ricos da região os resultados se aproximam dos que têm o SGI". (VEJA, 2007, p. 22)

\section{2 - A natureza e especificidade do processo pedagógico}

A natureza e especificidade do processo pedagógico envolto nas relações humanas de trabalho entre professor e educando apresentam características que diferem do processo de trabalho de outras atividades. Sob a luz dos trabalhos teóricos de PARO (2012) e SOUZA (2008) pretendo discorrer sobre as características específicas que acontecem no processo pedagógico de ensino-aprendizagem e refutar a tese defendida nos conteúdos da revista Veja, em que para conquistar uma educação pública de qualidade é necessário transpor os mecanismos de administração próprios do sistema capitalista, especialmente pela lógica gerencial, para as escolas públicas.

Para consecução de tal objetivo, primeiramente é importante destacar uma reflexão que PARO faz acerca dos objetivos gerais, abstraídos dos condicionantes capitalistas, que a administração escolar deve promover:

Uma Administração Escolar que pretenda promover a racionalização das atividades no interior da escola deve começar, portanto, por examinar a própria especificidade do processo de trabalho que aí tem lugar. Este aspecto, embora muito pouco explorado, mesmo no seio de uma concepção crítica da educação e, em especial, da Administração Escolar, precisa ser mais bem analisado, inclusive como meio para uma negação radical da tendência à aplicação, na escola, da administração empresarial capitalista. (PARO, 2012, p. 178)

A administração empresarial capitalista movimenta-se no sentido da produção do lucro. Esse é o objetivo último que os capitalistas têm. Nesse sentido, a escola quando se 
apropria da lógica administrativa capitalista para organizar e nortear o seu trabalho entra em conflito com a função essencial da escola que compreende no compartilhamento de todo o conhecimento historicamente produzido pelo homem.

Em outras palavras, enquanto a empresa capitalista alcança com grande eficiência seu objetivo último de realizar a mais-valia, atendendo, assim, aos interesses de uma classe minoritária, que são antagônicos aos interesses da sociedade como um todo, a escola, pela sua ineficiência na busca de seus objetivos educacionais, acaba por colocar-se também contra os interesses gerais da sociedade, uma vez que mantém apenas na aparência sua função específica de distribuir a todos o saber historicamente acumulado. (PARO, 2012, p. 177)

Sendo assim, a escola precisa ser composta de uma racionalidade especifica a fim de que possa alcançar uma transformação social.

Ou seja, se estamos convencidos de que a maneira de a escola contribuir para a transformação social é o alcance de seus fins especificamente educacionais, precisamos dotá-la da racionalidade interna necessária à efetiva realização desses fins. (...) entretanto, a buscadessa racionalidade não pode consistir no mero transplante, para a situação escolar, dos mecanismos administrativos da empresa capitalista. A Administração Escolar precisa saber buscar na natureza própria da escola e dos objetivos que ela persegue os princípios, métodos e técnicas adequados ao incremento de sua racionalidade. (PARO, 2012, p. 177)

Para a necessidade de entendimento da especificidade do caráter pedagógico, PARO, se utiliza do aporte marxiano que diferencia trabalho material e trabalho nãomaterial.

O trabalho material produz um objeto tangível, enquanto o trabalho não material produz um serviço. Enquanto um sapato pode ser exemplo de um trabalho material, a produção de um livro, por parte do escritor, é um tipo trabalho não-material. Além disso, 
existem duas naturezas de trabalho não material: Um que ocorre a separação entre produção e consumo, como o caso do livro, e outro em que produção e consumo ocorrem ao mesmo tempo, como é o exemplo do professor. Nesse caso, a natureza do produto pode ocorrer durante o processo de produção a perdurar pela vida toda de uma pessoa. (SOUZA, 2008)

Portanto num processo de produção material, temos a matéria-prima, o produtor e o produto final. No caso da produção não-material que contempla a especificidade do trabalho pedagógico, nós temos o aluno como matéria-prima, produtor e produto ao mesmo tempo, no mesmo processo de trabalho a atividade desenvolvida é produto e produtora, pois a natureza do aluno se modifica ao longo do processo educacional, está em transformação ao passo que tem sua natureza transformada.

Na medida, pois, em que, por sua própria natureza humana, o aluno age no processo produtivo escolar, com vistas à consecução de um fim educativo, revela-se essa sua nova dimensão que é a de produtor ou, melhor dizendo, coprodutor, juntamente com as outras pessoas envolvidas também ativamente no processo pedagógico. Ao apresentar esta dimensão não apenas de objeto de trabalho mas também de produtor, ou seja, de realizador de sua própria educação, configura-se a participação do aluno na atividade educativa não só como objeto mas igualmente como sujeito da educação. (PARO, 2012, p. 186)

Ainda corroborando com a mesma idéia, PARO aponta: 
Na produção pedagógica, embora exista também essa categoria de saber que instrumentaliza os métodos e técnicas de ensino-aprendizagem, há uma espécie de saber que se comporta muito mais como matéria-prima, incorporando-se ao produto final. Esse saber não é nada mais que o "saber historicamente acumulado", o qual não permanece apenas no ato de produzir a educação, mas ultrapassa esse processor, de forma análoga à da matéria-prima na produção material, que entra no processo de produção como matéria-prima e sai como parte componente do novo produto. (PARO, 2012, p. 193)

Por essa razão apontada que é impossível transpor as teorias administrativas e gerenciais capitalistas para dentro da escola sem comprometer a racionalidade interna especifica ao processo pedagógico de ensino-aprendizagem. SOUZA (2008) também aponta para o mesmo fato:

Na produção material, pode-se conseguir produtos de boa qualidade a partir de trabalhadores descontentes. Na escola a não identificação dos agentes com os objetivos estabelecidos compromete necessariamente a qualidade dos resultados, fato que pode permanecer oculto pela dificuldade de avaliação imediata do produto e do processo. Entendendo a educação como "atualização histórico-cultural" com vistas à emancipação humana e a escola como "agência encarregada da educação sistematizada", portanto espaço forma da sociedade cuja atribuição consiste precisamente em promover a atualização histórico-cultural, a participação dos envolvidos deve dar-se de forma intencional, pois não cabe pensar que a emancipação possa ocorrer de forma espontânea ou menos ainda admitir que a emancipação ocorra de forma concedida e imposta. (SOUZA, 2008, p. 124)

Portanto, uma educação que almeje alcançar os objetivos de transformação social deve respeitar a racionalidade interna ao processo de trabalho desenvolvido entre educadores e educandos. Racionalização que os mecanismos gerenciais e que tentam transformar a escola em uma empresa, não irão contemplar. 
Em resumo, (...) como característica de toda educação, a apropriação do saber historicamente acumulado só se dá, na escola, a partir de uma relação na qual o aluno entra não apenas como objeto mas também como sujeito da educação. Como sujeito, ele participa ativamente do processo, tornando-se coprodutor da atividade pedagógica. Como objeto, ele entra, por um lado, na condição de beneficiário, ou seja, de consumidor, o que implica que, num primeiro momento, o consumo do produto escolar se dê simultaneamente a sua produção; mas, também como objeto da educação, o aluno entra, por outro lado, na condição de objeto de trabalho, no sentido de que ele se transforma, no processo, resultando em um produto que permanece para além do ato de produção, o que significa que o consumo não se restringe à atividade produtiva, mas se prolonga para além dela. A presença do aluno como objeto e sujeito da educação supõe necessariamente a existência do saber, que é o que dá substância e conteúdo à própria relação educador/educando. Esse saber, como matéria-prima do processo, não pode ser alienado do ato de produção, o que exige que o próprio educador, como trabalhador, não seja expropriado do saber que ele precisa deter para "passar" ao educando no processo de produção pedagógico. (PARO, 2012, p. 194-195)

Assim sendo, percebemos que a tese defendida pelos autores, entrevistados, contida nas reportagens, que uma educação de qualidade passa pela adoção de mecanismos que norteiam o setor privado, seja pela apropriação de uma racionalidade gerencial ligada a teóricos da administração especificamente capitalista, seja pela compra de produtos educacionais do setor privado, seja pela parceria com o mesmo por meio de fundações com o intuito de aplicar consultorias ou até mesmo gerenciamento direto da parte administrativa nas escolas, vai de encontro com ao caráter especifico encontrado no processo pedagógico. 


\section{5- CONSIDERAÇÕES FINAIS}

Esta pesquisa teve como objetivo desvelar a concepção de gestão escolar publicada em um veículo da grande mídia impressa. Nesse sentido, a revista Veja foi tomada como objeto de pesquisa na tentativa de construir um debate acerca do que é veiculado numa mídia de alcance nacional e o campo acadêmico a respeito do tema gestão escolar e políticas educacionais.

Para alcançar esse fim foi necessário caracterizar e analisar as publicações que estavam dentro do recorte temporal proposto pela pesquisa. Sendo assim, foi utilizada a metodologia de análise de conteúdo na perspectiva de Laurence Bardin. Metodologia que propiciou a quantificação e segmentação dos conteúdos analisados, de temas gerais até temas mais específicos.

No capítulo 1 apresentei os objetivos do trabalho seguido da metodologia e dos procedimentos metodológicos para alcançar os fins desejados para este trabalho. No capítulo 2 foi apresentada uma caracterização geral do grupo Abril, da Revista Veja e dos principais atores que escrevem na revista Veja ou são chamados para darem suas opiniões em espaços nobres da revista. Além disso, foi feito uma tentativa inicial de esmiuçar as atividades e parcerias que os atores em questão e o grupo abril tem com o setor privado e grupos empresariais.

No capitulo 3 apresento a maior parte dos dados levantados na pesquisa. Segmento eles desde abrangências mais gerais, como tema educação, até temáticas mais especificas como diretor escolar. Importante destacar que reside nesse capitulo, talvez, o maior achado desta pesquisa: A partir do ano de 2006 há uma guinada editorial da Revista Veja no sentido de publicar cada vez mais sobre educação e, por conseguinte, gestão escolar.

No capítulo 4 o esforço foi em demonstrar e elucidar a idéia editorial principal que a Revista Veja defende: a transposição da lógica do setor privado e das teorias de administração tipicamente capitalistas, como a administração gerencial, para dentro da educação e escola pública. Para contrapor essa idéia foi utilizado o aporte teórico de Vitor Paro que trata da natureza especifica do processo pedagógico. 
Portanto, ao longo deste trabalho foi demonstrado que a revista Veja, por meio de seus conteúdos publicados em educação e, sobretudo gestão escolar, apresentou uma característica peculiar: a partir do ano de 2006 começa a intensificar a quantidade de inserções desses conteúdos. Acredito que esse seja o principal achado dessa pesquisa que abre um escopo para futuras pesquisas que possam somar esforços com o intuito de esmiuçar as possíveis razões que levaram a esta escolha editorial. Esta pesquisa apresenta possíveis caminhos para serem seguidos por outros pesquisadores, e também por mim futuramente. Porém, mesmo com caminhos a serem desbravados, é possível fazer algumas inferências sobre os resultados alcançados.

Primeiramente, é relevante pontuar que tanto Cláudio Moura Castro quanto Gustavo loschpe tem atuação muito próxima ao setor privado. Seja participando de Institutos que disseminam os valores liberais e capitalistas. Seja por meio do trânsito facilitado em serem convidados a exporem suas opiniões em outras mídias (TV, revistas, etc). Seja pela relação direta em ocupações como consultores de empresas educacionais (PITAGORAS no caso do Cláudio Moura Castro) ou fundações que apresentam e apresentaram parcerias com entes públicos (Instituto Unibanco, Instituto Ayrton Senna, etc). Além disso, Gustavo loschpe também aparece no quadro diretivo da empresa de sua família (Maxion-loschpe) que tem uma fundação própria (Formare) que atua na área de formação de profissionais para o mercado de trabalho. Sobre Cláudio Moura Castro, importante ressaltar novamente sua atuação em cargos importantes em organismos multilaterais como o BID. Ademais, fizeram parte da fundação do Todos pela Educação. Além desses articulistas, também tivemos presente em entrevistas nas páginas amarelas pessoas importantes como Paulo Renato de Souza, Maria Helena Guimarães. Estes que participaram da entrevista enquanto secretários da educação do Estado de São Paulo, também apresentam relações muito próximas com o setor privado. Até mesmo fazendo parte de conselhos consultivos de Institutos, Fundações que tem ou tiveram parcerias com o setor público.

Tendo em vista que esses sujeitos defendem concepções de gestão muito semelhantes ao longo dos conteúdos desvelados pela pesquisa. Concepções que elogiam o setor privado e defende a aplicação de mecanismos das empresas capitalistas como bonificação, lógica gerencial, meritocracia, para dentro das escolas públicas. Levanto um 
questionamento: Pode-se considerar imparcial alguém que defende parcerias com o setor privado ou aplicação da lógica gerencial nas escolas, mas apresenta relações muito intimas com o setor o qual está defendendo? Penso como disse, que esta pesquisa abre um vácuo para novas pesquisas que possam elucidar ainda mais estas questões.

Para além dessas constatações, a pesquisa teve o intuito de tentar dar uma resposta as publicações que defendem a transposição da lógica do setor privado para às escolas públicas. PARO nos ajuda a compreender porque não é possível fazer essa transposição:

Todas essas características da atividade pedagógica escolar servem, pois, para evidenciar a especificidade da escola e a impossibilidade de generalização, aí, do modo de produzir autenticamente capitalista; ou seja, tal modo de produzir, uma vez que se fundamenta nas relações sociais de produção, que se dão no nível da infraestrutura econômica, não pode generalizar-se na escola, sob pena de descaracterizá-la de sua condição específica de entidade pertencente à superestrutura da sociedade. Essa condição superestrutural advém do fato de as relações sociais que a caracterizam não serem do tipo das relações sociais de produção que têm lugar no nível econômico, infraestrutural: a escola, como entidade que lida com o saber e sua apropriação, fundamenta-se, em vez disso, em relações que decorrem das representações que os homens elaboram a partir das relações que se dão no nível da produção social de sua existência. Em outras palavras, a escola se pauta por relações que dizem respeito â forma pela qual os homens tomam consciência da própria realidade concreta, descaracterizando-se, portanto, toda vez que ela deixa de fundar-se nessas relações para pautar-se por relações próprias do nível econômico da sociedade." (PARO, 2012, p. 195-196)

Corroborando com as idéias de PARO e trazendo uma perspectiva de participação, SOUZA (2008) apresenta: 
Por isso é preciso tomar como fundamento a relação entre uma educação emancipadora e a gestão democrática da escola, já que é impossível fazer educação de forma autoritária. E é também inaceitável pensar em gestão democrática da escola sem a participação dos pais na forma de "partilha de poder" (LE BOTERF, 1982), pois daí estar-se-ia restringindo a participação somente aos servidores da escola, o que já significaria uma gestão autoritária. Também não se trata da participação na forma de adoção voluntária de parte do financiamento da escola pela comunidade. (SOUZA, 2013, p. 128)

Fecho este trabalho, portanto, com a perspectiva de ter tentado contribuir de alguma forma ao campo acadêmico e com futuros estudos que tratem desta temática ou a utilizem como fonte de outras pesquisas. 


\section{6 - REFERÊNCIAS BIBLIOGRÁFICAS}

ABRIL. Disponível em: <http://grupoabril.com.br/pt/o-que-fazemos/Mídia/iniciativas>. Acesso em: 02 de nov. 2015.

ADRIÃO, T.; PERONI, V. Análise das consequências de parcerias firmadas entre municípios brasileiros e a Fundação Ayrton Senna para a oferta educacional. Relatório de pesquisa - CNPq, 2010.

, T. M. F; PERONI, V. M. V. Consequências da atuação do Instituto Ayrton Senna para a gestão da educação pública: observações sobre 10 estudos de caso. Práxis Educativa, v. 6, p. 45-53, 2011.

, T. M. F. Notas sobre o Grupo de Estudos e Pesquisas em Política Educacional GREPPE. Jornal de Políticas Educacionais. Curitiba, n.12, p. 51-56, 2012.

, T.; GARCIA, T.; BORGHI, R.; BERTAGNA, R.; PAIVA, G.; XIMENES, S. Sistemas de Ensino Privado na Educação Pública Brasileira: consequências da mercantilização para o direito à educação. Relatório de Pesquisa. GREPPE, Ação Educativa. 2015.

ALONSO, M.. O papel do diretor na administração escolar. São Paulo: Difel, 1976

ARROYO, M. Administração da educação, poder e participação. In: Educação e

Sociedade. São Paulo: Cortez e Moraes, ano I, n. 2, jan. 1979.

AZANHA, J.M.P. Autonomia da escola e proposta pedagógica. SEE, A escola de cara nova. Planejamento. São Paulo: SE/CENP, 2000, p.18-24. BARDIN, Laurence. Análise de conteúdo. Lisboa: Edições 70, 1977.

BOTTOMORE, T. Dicionário do Pensamento Marxista. Rio de Janeiro, Jorge Zahar Editor, 1997.

BRESSER-PEREIRA, Luiz Carlos. Da Administração Pública burocrática à gerencial. Revista do Serviço Público, v. 47, n.1, p. 7-29, 1996.

CABRITO, B. AVALIAR A QUALIDADE EM EDUCAÇÃO: AVALIAR O QUÊ? AVALIAR COMO? AVALIAR PARA QUÊ?Cad. Cedes, Campinas, vol. 29, n. 78, p. 178-200, maio/ago. 2009

CANDIDO, A. A estrutura da escola. In: PEREIRA, Luiz; FORACCHI, Marialice M. 
Educação e sociedade (Leituras de Sociologia da Educação). 12. ed. São Paulo: Ed. Nacional, 1985, p. 107- 128.

CORREA, B. C. ; GARCIA, T. O. G. . Administração Escolar: a centralidade do diretor em questão.. In: X Seminário Estadual da Associação Nacional de Política e Administração de Educação, 2006, São Bernardo do Campo. Anais do X Seminário Estadual da Associação Nacional de Política e Administração de Educação, 2006. v. 01. p. 1-16.

CASTRO, C. M. Acelera Ayrton Senna. Veja, São Paulo, Edição 1540, p. 103, 1 abr. 1998. , C. M. Em se plantando dá. Veja, São Paulo, Edição 1949, p. 20, 29 mar 2006. , C. M. A tríplice aliança. Veja, São Paulo, Edição 1994, p. 22, 7 fev. 2007. , C. M. Satanás apostilado? Veja, São Paulo, Edição 2022, p. 20, 22 ago. 2007. , C. M. Salário de professor. Veja, São Paulo, Edição 2047, p. 16, 13 fev. 2008. CASTRO, C. M. Disponível em: <http://claudiomouracastro.com.br/>. Acesso em: 15 de nov. 2015.

CIVITA,

Roberto.

Disponível

em: $<$ http://publiabril.abril.com.br/marcas/veja/plataformas/revista-impressa>. Acesso em: 18 de out. 2015.

EDUCAR PARA CRESCER. Disponível em: <http://educarparacrescer.abril.com.br/>. Acesso em: 05 de nov. 2015.

EDUCAR PARA CRESCER. Disponível em:

$<$ http://educarparacrescer.abril.com.br/indicadores/singapura-pode-ensinar-nossa-

reforma-educacional-948280.shtml>. Acesso em: 14 de mai. 2016.

FORMARE. Disponível em: <www.formare.org.br>. Acesso em: 28 de out. 2015.

FÓRUM NACIONAL DE EDUCAÇÃO - LIDE. Disponível em: $<$ https://economia.uol.com.br/noticias/pr-newswire/2015/10/21/forum-nacional-deeducacao-do-lide-ve-o-tema-como-primordial-para-o-avanco-do-pais.htm >. Acesso em: 25 de mai. 2016.

FREITAS, Luiz Carlos de. Os reformadores empresariais da educação: a consolidação do neotecnicismo no Brasil. In: Fontoura, H. A.. (Org.). Políticas públicas e movimentos sociais. Rio de Janeiro: ANPED Sudeste, 2011, v. 3, p. 72-90.

FUNDAÇÃO IOSCHPE. Disponível em: <http://fiochpe.org.br>. Acesso em: 30 de out 2015. 
FUNDAÇÃO VICTOR CIVITA. Disponível em: <www.fvc.org.br>. Acesso em: 05 de nov. 2015.

INSPER. Disponível em: <http://www.insper.edu.br/catedras/instituto-ayrton-senna/>. Acesso em: 19 de nov. 2015.

INSPER. Disponível em: <http://www.insper.edu.br/institucional/o-insper/historico/>. Acesso em: 19 de nov. 2015.

INSTITUTO MILLENIUM. Disponível em: <http://www.institutomillenium.org.br>. Acesso em: 25 de nov. 2015.

INSTITUTO UNIBANCO. Disponível em: <http://www.institutounibanco.org.br/membrosgovernanca/claudio-de-moura-castro>. Acesso em: 18 de nov. 2015.

IOSCHPE, G. O que os candidatos estão dizendo... E o que funciona mesmo. Veja, São Paulo, Edição 2290, p. 112, out. 2012.

GARCIA,T.O.G. Gestão Democrática e participação dos educandos: um caso em estudo. 2003. Tese (Doutorado em Educação)- Faculdade de Educação, Universidade de São Paulo.

JUNQUILHO, G. S. Teorias da administração pública / Gelson Silva Junquilho. Florianópolis : Departamento de Ciências da Administração / UFSC; [Brasília] : CAPES : $U A B, 2010.182 p$. : il.

LIMA, L. C. A escola como organização educativa: Uma abordagem sociológica. São Paulo: Cortez, 2001.

PAULA, A. P. P. Administração pública brasileira. Entre o gerencialismo e a gestão social. RAE-DEBATE. ADMINISTRAÇÃO PÚBLICA BRASILEIRA ENTRE O GERENCIALISMO E A GESTÃO SOCIAL, p. 36-49, 2005.

PARO, V. H.. Administração escolar: Introdução Crítica. - 17. ed. rev. e ampl. - São Paulo: Cortez, 2012.

, V.H Educação como exercício de poder. São Paulo: Cortez, 2008. PINTO, J. M. R. (Org.) ; SOUZA, S. A. (Org.) . Para onde vai o dinheiro: caminhos e descaminhos do financiamento da educação. 1. ed. São Paulo: Xamã Editora, 2014. 208p PRESOTTI, KARINE. REPRESENTAÇÕES DO EXAME NACIONAL DO ENSINO MÉDIO NA REVISTA VEJA (1998-2011) 
SOUZA, S. A. . Educação e responsabilidade empresarial: ?novas? modalidades de atuação da esfera privada na oferta educacional. Educação \& Sociedade (Impresso), v. 30, p. n.108, 2009.

, S. A. ; As diretrizes do Instituto Ayrton Senna como política pública e a parceria com o município de São José dos Pinhais-PR. Revista FAED - UNEMAT, v. 18, p. 163-182, 2012. 37

S. A. ; Educação, trabalho voluntário e responsabilidade social da empresa: "AMIGOS DA ESCOLA" e outras formas de participação. 2008.

, S. A. ; Formas Renovadas de Privatização da Educação no Brasil: o trabalho voluntário e a responsabilidade social da empresa (RSE).. Educação (Rio Claro. Impresso), v. 19, p. 1-16, 2009.

, S. A. ; Gestão escolar compartilhada: democracia ou descompromisso?. 1. ed. São Paulo: Xamã Editora, 2001. v. 01.215p .

, S. A. ; Trabalho voluntário e responsabilidade social da empresa: novas formas de exploração da força de trabalho e de extração da mais-valia. Novos Temas, v. 3, p. 47-63, 2011.

VEJA. Veja, São Paulo, Edição 1969, p. 20, 16 de ago. 2006 . Veja, São Paulo, Edição 1971. p. 104-105, 30 ago. 2006. . Veja, São Paulo, Edição 1995, p. 94-95, 14 fev. 2007. . Veja, São Paulo, Edição 2035, p. 11-15, 21 nov. 2007. . Veja, São Paulo, Edição 2047, p. 9-13, 13 fev. 2008. . Veja, São Paulo, Edição 2051, p. 78, 12 mar. 2008. . Veja, São Paulo, Edição 2128, p. 108, 2 set. 2009. . Veja, São Paulo, Edição 2136, p. 19-23, 28 out. 2009. . Veja, São Paulo, Edição 2283, p. 21, 22 ago. 2012. 